\title{
Telomere Protection Mechanisms Change during Neurogenesis and Neuronal Maturation: Newly Generated Neurons Are Hypersensitive to Telomere and DNA Damage
}

\author{
Aiwu Cheng, ${ }^{1}$ Kazuo Shin-ya, ${ }^{2}$ Ruiqian Wan, ${ }^{1}$ Sung-chun Tang, ${ }^{1,3}$ Takumi Miura, ${ }^{1}$ Hongyang Tang, ${ }^{1}$ Rina Khatri, ${ }^{1}$ \\ Marc Gleichman, ${ }^{1}$ Xin Ouyang, ${ }^{1}$ Dong Liu ${ }^{1}$ Hae-Rong Park, ${ }^{2}$ Jeffrey Y. Chiang, ${ }^{4}$ and Mark P. Mattson ${ }^{1,5}$ \\ ${ }^{1}$ Laboratory of Neurosciences, National Institute on Aging Intramural Research Program, Baltimore, Maryland 21224, ${ }^{2}$ Institute of Molecular and Cellular \\ Biosciences, University of Tokyo, Tokyo, 113-8656, Japan, ${ }^{3}$ Stroke Center, Neurology Department, National Taiwan University Hospital, Taipei, Taiwan, \\ ROC 100, ${ }^{4}$ Experimental Immunology Branch, National Cancer Institute, Bethesda, Maryland 20892, and 5 Department of Neuroscience, Johns Hopkins \\ University School of Medicine, Baltimore, Maryland 21205
}

Telomeres are DNA-protein complexes at the ends of eukaryotic chromosomes that play an important role in maintaining the integrity of the genome. In proliferative stem cells and cancer cells, telomere length is maintained by telomerase, and telomere structure and functions are regulated by telomere-associated proteins. We find that telomerase levels are high in embryonic cortical neural progenitor cells (NPCs) and low in newly generated neurons (NGNs) and mature neurons (MNs). In contrast, telomere repeat-binding factor 2 (TRF2) expression is undetectable in early brain development in vivo and in cultured NPCs and is expressed at progressively higher levels as NPCs cease proliferation and differentiate into postmitotic neurons. The telomere-disrupting agent telomestatin induces a DNA damage response and apoptosis in NGNs (which have low levels of TRF2 and telomerase), whereas NPCs (which have high levels of telomerase) and MNs (which have high levels of TRF2) are resistant to telomere damage. Overexpression of TRF2 in NGNs protects them against death induced by telomestatin and other DNA-damaging agents. Knockdown of TRF2 expression in MNs and knock-out of telomerase reverse transcriptase in NPCs increased their sensitivity to telomere- and DNA-damaging agents but did not affect the vulnerability of NGNs. These findings suggest that TRF2 and telomerase function as distinct telomere protection mechanisms during the processes of neurogenesis and neuronal maturation and that hypersensitivity of NGNs to telomere damage results from relative deficiencies of both telomerase and TRF2.

Key words: apoptosis; DNA; histone modification; neurogenesis; neuronal death; neuronal progenitor cell

\section{Introduction}

During brain development, neurons are generated from proliferating neural progenitor cells (NPCs) in the telencephalic ventricular zone (VZ) (Price et al., 1992; McConnell, 1995); in the adult brain, NPCs are located mainly in the subventricular zone (SVZ) of the cerebral cortex and the hippocampal dentate gyrus (Gross, 2000; Lie et al., 2004). During neurogenesis NPCs cease dividing and then differentiate into newly generated neurons (NGNs), which then undergo a process of maturation by growing axons and dendrites and forming synapses with other neurons.

Many NGNs in the developing and adult brain undergo a form of programmed cell death called apoptosis, whereas NPCs

\footnotetext{
Received July 20, 2006; accepted Feb. 20, 2007.

This research was supported by the National Institute on Aging Intramural Research Program. We thank Dr. Karen Hathcock and Dr. Richard J. Hodes for critical reading of this manuscript and Mohammed Mughal for help in managing the timed pregnant mice colony.

Correspondence should be addressed to either of the following: Aiwu Cheng, National Institute on Aging, Gerontology Research Center 4F16, 5600 Nathan Shock Drive, Baltimore, MD 21224, E-mail: chengai@grc.nia.nih.gov; or Mark P. Mattson, National Institute on Aging, Gerontology Research Center 4F01, 5600 Nathan Shock Drive, Baltimore, MD 21224, E-mail: mattsonm@grc.nia.nih.gov.

DOI:10.1523/JNEUROSCI.0590-07.2007

Copyright $\odot 2007$ Society for Neuroscience $\quad$ 0270-6474/07/273722-12\$15.00/0
}

and mature neurons (MNs) in close proximity do not die (Kuan et al., 2000; Miller et al., 2000; Lee et al., 2002). It is not known why NGNs are hypersensitive to apoptosis, but it has been suggested that DNA damage and/or cell cycle-related signals may be involved (Frank et al., 2000; Lee et al., 2000; Herrup et al., 2004; Kruman et al., 2004).

Emerging evidence suggests that telomeres, the specialized ends of the chromosomes comprising noncoding DNA sequences and several associated proteins, may play important roles in development of the nervous system. In proliferative embryonic cells and tumor cells, telomere length is maintained by telomerase, an enzyme that adds six-base DNA repeats (TTAGGG) onto the telomeric ends of chromosomes (Blackburn, 2001; Chan and Blackburn, 2004). Telomerase is present at high levels in NPCs in the developing (Klapper et al., 2001; Cai et al., 2002) and adult (Caporaso et al., 2003) brain; during development, telomerase activity rapidly decreases as NPCs cease dividing and differentiate into neurons (Kruk et al., 1996; Klapper et al., 2001). One function of telomerase in neurogenesis may be to promote the survival of NPCs and NGNs (Fu et al., 1999, 2000; Zhang et al., 2003). Telomere ends are capped and telomeric DNA is organized into a t-loop structure by telomere-associated 
proteins, which protect them from degradation or fusion with other chromosomes (McEachern et al., 2000). Telomere repeat binding factor 2 (TRF2) binds directly to double-stranded telomeric DNA and facilitates t-loop formation (Bilaud et al., 1997; Broccoli et al., 1997; Griffith et al., 1999). TRF2 can prevent cellular senescence and apoptosis in non-neural cells by protecting telomeres and/or by inhibiting telomere-associated DNA damage response pathways involving ataxia telangiectasia mutated (ATM) and p53 (Karlseder et al., 1999, 2002, 2004; Bradshaw et al., 2005). If and how TRF2 functions in development of the nervous system is unknown.

We found that NGNs are highly sensitive to telomere damage compared with NPCs and MNs. Apoptosis induced by telomere damage was associated with the phosphorylation of $\gamma-\mathrm{H} 2 \mathrm{~A}$ histone family, member X (H2AX) and poly(ADP-ribose) polymerase (PARP) activation, which occurred before mitochondrial alterations and nuclear condensation and fragmentation. Overexpression of TRF2 in NGNs suppressed DNA damage response and thereby protected NGNs against apoptosis, whereas knockdown of TRF2 sensitized MNs to DNA damage. In addition, knock-out of telomerase reverse transcriptase (TERT) sensitized NPCs to DNA damage. Thus, telomeres play important roles in determining the intrinsic vulnerability of neural cells to telomere/DNA damage encounters in the processes of neural differentiation and maturation.

\section{Materials and Methods}

Mice and tissue preparation. Timed pregnant mice (C57BL/6) were purchased from The Jackson Laboratory (Bar Harbor, ME). Methods for the generation of TERT ${ }^{-1-}$ mice have been described previously (Chiang et al., 2004). The TERT $T^{-/-}$mice used in the present study had been backcrossed to C57BL/6 through at least 10 generations. First-generation homozygous TERT ${ }^{-/-}$male and female mice were bred to generate timed pregnancies. Pregnant mice were killed using isoflurane anesthesia, the cerebral wall at early development stages [embryonic day 12 (E12), 14 and 16] or cerebral cortex at later developmental stages [E18, postnatal day $0(\mathrm{P} 0), \mathrm{P} 5, \mathrm{P} 15]$ or in adults (P60) were dissected out, and tissues were either used to prepare dissociated cell or neurosphere cultures or were stored at $-80^{\circ} \mathrm{C}$. All procedures were approved by the National Institute on Aging Animal Care and Use Committee and were in compliance with National Institutes of Health guidelines.

Cell cultures and experimental treatments. Pregnant mice were killed on gestational day 12, and embryos were harvested and their brains were removed. Meninges were removed from the brain, and the cortical neuroepithelium was dissected and collected in cold HBSS (Invitrogen, Carlsbad, CA). The cells were dissociated with a fire-polished glass pipette and were then plated on poly-L-lysine-coated glass coverslips or plastic culture dishes. For NPC cultures, the cells were plated at 50,000 per $\mathrm{cm}^{2}$ in DMEM/F-12 medium containing B27 supplements (Invitrogen) and $30 \mathrm{ng} / \mathrm{ml}$ basic fibroblast growth factor (bFGF) (Sigma, St. Louis, MO) or were cultured in noncoated flasks to form neurospheres. Neurospheres from TERT ${ }^{-/-}$mice were established from second generation of E12 TERT ${ }^{-/-}$mice (G2). To induce differentiation of NPCs, the cells were plated at 20,000 per $\mathrm{cm}^{2}$ in serum- and bFGF-free DMEM/ F-12 containing B27 supplements. Experimental treatments included the following: staurosporine (STS), etoposide, and camptothecin (Sigma); telomestatin (TMS) (from the laboratory of K.S.-y.) (Shin-ya et al., 2001; Kim et al., 2002, 2003) and zVAD-fmk (N-benzyloxycarbonyl-Val-AlaAsp-fluoromethyl ketone) (Cell Signaling Technologies, Beverly, MA), which were prepared as $500-1000 \times$ stocks in dimethylsulfoxide; and 3 -aminobenzamide (Sigma) prepared as 200-500X stocks in culture medium. Treatments were administered by direct dilution into the culture medium, and an equivalent volume of vehicle was added to control cultures.

Assessment of cell survival. After exposure to experimental treatments, cells were fixed in $4 \%$ paraformaldehyde in PBS for $30 \mathrm{~min}$ at room temperature and then washed with PBS. Cells were then either stained with the DNA-binding dye Hoechst $33258(5 \mu \mathrm{g} / \mathrm{ml})$ in PBS for $2 \mathrm{~h}$ at room temperature or overnight at $4^{\circ} \mathrm{C}$. Alternatively, fixed cells were permeabilized with $0.2 \%$ Triton X-100 and were then stained with propidium iodide (PI) $(5 \mu \mathrm{g} / \mathrm{ml}$ for $10 \mathrm{~min}$ at room temperature). Coverslips were mounted onto glass slides and examined under epifluorescence illumination using a $40 \times$ objective lens. Cells were considered apoptotic if their nuclear chromatin was condensed or fragmented or viable if their chromatin was diffuse and evenly distributed throughout the nucleus. To further confirm and detect apoptotic DNA fragmentation, a terminal deoxynucleotidyl transferase-mediated biotinylated UTP nick end labeling (TUNEL) kit (R \& D Systems, Minneapolis, MN) was used. Briefly, the cells were fixed with $4 \%$ paraformaldehyde in PBS for $30 \mathrm{~min}$ and washed with PBS, pH 7.4. After blocking of endogenous peroxidases, the cells were incubated at $37^{\circ} \mathrm{C}$ for $1 \mathrm{~h}$ in a reaction mixture containing terminal transferase, biotinylated nucleotide (dNTP), or PBS as a control. Cells were then incubated in the presence of streptavidinconjugated horseradish peroxidase for $20 \mathrm{~min}$ at room temperature. After rinsing in PBS, DNA strand breakage was visualized in the presence of horseradish peroxidase substrate. The apoptotic cells exhibited dark blue nuclear staining. Approximately 500 cells on each coverslip were scored; three separate coverslips were assessed for each condition in each experiment, and three separate experiments were performed for Hoechst 33258, PI, and TUNEL staining analyses. For evaluating cell death in neurospheres, confocal images of Hoechst staining were acquired in $Z$-sectioning manner; the alive and dead cells (condensed nuclei) were quantified in each neurosphere. Approximately 10 neurospheres were evaluated for each condition per experiment.

Immunoblot analysis. Tissues or cells were solubilized in SDS-PAGE sample buffer, and the protein concentration in each sample was determined using a Bio-Rad (Hercules, CA) protein assay kit with bovine serum albumin as the standard. Proteins (50 $\mu \mathrm{g}$ protein per lane) were then resolved on $5-12 \%$ SDS polyacrylamide gels and electrophoretically transferred to a nitrocellulose membrane. Membranes were blocked with $4 \%$ nonfat milk in TBST (Tris-HCl-based buffer with $0.2 \%$ Tween 20 , $\mathrm{pH}$ 7.5) and then incubated for overnight at $4^{\circ} \mathrm{C}$ in the presence of primary antibody. Cells were then incubated for $1 \mathrm{~h}$ in the presence of a 1:5000 dilution of secondary antibody ( $\operatorname{IgG}$ ) conjugated to horseradish peroxidase. Reaction product was visualized using an enhanced chemiluminescence Western blot detection kit (Amersham Biosciences, Arlington Heights, IL). The primary antibodies included anti-PARP (mouse, 1:1000; PharMingen, San Diego, CA), anti-actin (mouse, 1:10,000; Sigma), anti-nestin (mouse, 1:500; Chemicon, Temecula, CA), anti-Sox2 (SRY-box containing gene 2) (rabbit, 1:500; Chemicon), antisynapsin (rabbit, 1:1000; Chemicon), anti-TRF2 (1:250; Imgenex, San Diego, CA), and anti- $\gamma \mathrm{H} 2 \mathrm{AX}$ (1:500; Upstate Biotechnology, Lake Placid, NY).

Histology and immunocytochemistry. Timed pregnant C57BL/6J mice at E16 and E18 were killed, embryos were removed and decapitated, and heads of fetal mice were fixed in $4 \%$ paraformaldehyde in PBS for $3 \mathrm{~d}$. P0, $\mathrm{P} 5$, and P15 mice were anesthetized and perfused transcardially with PBS, followed by $4 \%$ paraformaldehyde in PBS, $\mathrm{pH}$ 7.4. Brains were postfixed overnight. Brains were cryoprotected by immersing in $25 \%$ sucrose in PBS and embedded in Tissue-Tek (Sakura, Torrance, CA), and cryostat sections were cut in the coronal plane at a thickness of $30 \mu \mathrm{m}$. Brain sections were collected in PBS and processed for TRF2 immunostaining. Sections were incubated in $1 \% \mathrm{H}_{2} \mathrm{O}_{2}$ for $30 \mathrm{~min}$ to quench endogenous peroxidase activity, followed by incubation in a solution of

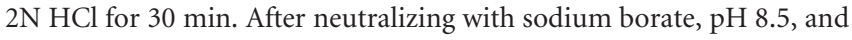
rinsing with $\mathrm{PBS}$, sections were incubated overnight with primary antibody (mouse anti-TRF2) at $4^{\circ} \mathrm{C}$ and then washed in PBS and further processed by using a Vector ABC Elite kit (Vector Laboratories, Burlingame, CA). The sections were further processed by incubation in a solution containing $0.035 \%$ diaminobenzidine and $0.01 \% \mathrm{H}_{2} \mathrm{O}_{2}$. The developed sections were mounted on Superfrost Plus slides, dehydrated in a graded ethanol series, and immersed in 100\% xylene for $15 \mathrm{~min}$. Sections were then coverslipped in Permount medium (Fisher Scientific, Bridgewater, $\mathrm{NJ}$ ). Cultured cells were exposed to experimental treatments, fixed in $4 \%$ paraformaldehyde in PBS for 30 min at room temperature, and 
then washed with PBS. The fixed cells were permeabilized with $0.2 \%$ Triton X-100 for $10 \mathrm{~min}$, followed by a $2 \mathrm{~h}$ incubation at room temperature in blocking solution ( $5 \%$ normal goat serum and $0.2 \%$ Triton $\mathrm{X}-100$ in PBS, $\mathrm{pH}$ 7.4) containing primary antibodies. After washing with PBS, cells were incubated for $2 \mathrm{~h}$ in PBS containing fluoresceinconjugated goat anti-mouse or rabbit IgG (1:200; Jackson ImmunoResearch, West Grove, PA). After washing with PBS, cultures were counterstained with PI. For bromodeoxyuridine (BrdU) and TRF2 immunocytochemistry, cells were incubated for $30 \mathrm{~min}$ in a solution of $2 \mathrm{~N} \mathrm{HCl}$ before processing for immunocytochemistry. The primary antibodies included anti- $\beta 3$-tubulin (Tuj1) (mouse, 1:100; Sigma), antiTuj1 (rabbit, 1:500; Covance, Berkeley, CA), anti-cytochrome $c$ (mouse, 1:200; PharMingen), anti-apoptosis-inducing factor (AIF) (mouse, 1:100; Chemicon), mouse anti-nestin IgG1 (1:200; Chemicon), antimitogen-activate protein 2 (mouse, 1:200; Sigma), anti-BrdU (mouse, 1:100, Becton Dickson, Mountain View, CA), and anti-TRF2 (mouse, 1:50; Imgenex). All of the images were acquired by laser scanning confocal microscopy (LSM 510; Zeiss, Oberkochen, Germany) using a $40 \times$ water-immersion objective (numerical aperture, 1.4). The excitation and emission wavelengths for PI were 543 and $585 \mathrm{~nm}$, respectively, and for fluorescein isothiocyanate were 488 and $515 \mathrm{~nm}$, respectively.

Adenovirus amplification, purification, and infection. HEK293T cells at $70-80 \%$ confluency were infected with adenovirus containing TRF2 cDNA (a generous gift from J. Karlseder, The Salk Institute, La Jolla, CA) or adeno- $\beta$-galactosidase (adeno- $\beta$ gal) (a generous gift from R. Xiao, National Institute on Aging, Baltimore, MD). Infected cells were harvested and pelleted by centrifugation, and the supernatant was removed from the cells. The cells were suspended in $8 \mathrm{ml}$ of sterile PBS and subjected to four cycles of freeze/thaw/vortex. The lysate was centrifuged at $7000 \times g$, and the clear virus-containing supernatant was transferred to a $50 \mathrm{ml}$ conical tube containing $4.4 \mathrm{~g}$ of $\mathrm{CsCl}$ and was mixed by vortexing. The solution was transferred to a ultracentrifuge tube and centrifuged at $32,000 \mathrm{rpm}$ in a Sw41 rotor for $18-24 \mathrm{~h}$. The fraction containing viral particles $(0.5-1 \mathrm{ml})$ was collected with a $3 \mathrm{cc}$ syringe and mixed with an equal volume of filter sterilized $2 \times$ storage buffer $(100 \mathrm{~mm} \mathrm{NaCl}, 1 \%$ BSA, 50\% glycerol, and $10 \mathrm{~mm}$ Tris, $\mathrm{pH} 8.0$ ). The viral titer was $\sim 1.5 \times$ $10^{6} \mathrm{pfu} / \mu \mathrm{l}$. The cultured cells were infected at a multiplicity of infection of $50 \mathrm{pfu} / \mathrm{cell}$.

RNA interference methods. Sequence-verified short hairpin RNA (shRNA) lentiviral plasmids (pLKO.1-purp) containing TRF2 (GenBank accession number NM_009353) target sequences (supplemental Fig. 2, available at www.jneurosci.org as supplemental material) and a nontarget sequence (as negative control) were purchased from Sigma MISSION shRNA-RNA interference as frozen bacterial glycerol stocks (Luria Broth, carbenicillin at $100 \mathrm{ng} / \mu \mathrm{l}$ and $10 \%$ glycerol) in Escherichia coli for propagation and downstream purification of the shRNA clones. For lentivirus packaging, subconfluent HEK293T cells in $10 \mathrm{~cm}$ culture dishes were cotransfected with lentiviral plasmid $(8 \mu \mathrm{g})$, lentiviral packaging vector (pCMV-dR8.91, $8 \mu \mathrm{g}$ ), and the vesticular stomatitis virus $\mathrm{G}$ glycoprotein expression vector pMD2G $(4 \mu \mathrm{g})$ using Fugene 6 reagent (Roche Applied Science, Indianapolis, IN). The viruses were collected from the culture supernatants on day 2 after transfection, concentrated to 10:1 using a Millipore (Billerica, MA) centrifugal filter (UFC900508). The lentiviral vector containing enhanced green fluorescent protein (EGFP) was simultaneously packaged using same protocol. Titers were determined by infecting HEK293T cells with serial dilutions of concentrated lentivirus and counting EGFP-positive cells after $48 \mathrm{~h}$ under fluorescent microscopy. For a typical preparation, the titer was $\sim 2 \times 10^{7}$ infection units (IU)/ml. Cultured neurons were incubated with lentivirus at $10 \mathrm{IU} /$ cell for $6 \mathrm{~h}$ and then changed to normal culture medium (DMEM/F-12 plus B27); experiments were performed $48 \mathrm{~h}$ after infection.

PARP activity assay. PARP activity is analyzed according to the instruction of PARP assay kit (Trevigen, Gaithersburg, MD). Briefly, primary cultured neurons $\left(2-3 \times 10^{6}\right)$ were collected and lysed in $0.1 \mathrm{ml}$ of $50 \mathrm{~mm}$ Tris, $\mathrm{pH}$ 8.0, $25 \mathrm{~mm} \mathrm{MgCl}_{2}$, and $1 \times$ proteinase inhibitor cocktail. The samples are sonicated on ice, and the disrupted cell suspensions were centrifuged at $3000 \times \mathrm{g}$ for $5 \mathrm{~min}$ at $4^{\circ} \mathrm{C}$ to remove insoluble material. The protein concentrations were determined using a Bio-Rad protein assay kit with bovine serum albumin as the standard. Proteins $(20 \mu \mathrm{g})$ from cell extract were incubated with $2 \mu \mathrm{Ci}$ of ${ }^{32} \mathrm{P}-\beta$-nicotinamide adenine dinucleotide $\left(\mathrm{NAD}^{+}\right)$(GE Healthcare, Little Chalfont, Buckinghamshire, UK), $10 \mu \mathrm{g}$ of activated DNA, and $10 \mu \mathrm{g}$ of histones for $10 \mathrm{~min}$ at room temperatures. Adding purified PARP enzyme is used as a positive control and omitting PARP enzyme as negative control. At the end of the incubation, ribosylated proteins were precipitate by adding $900 \mu \mathrm{l}$ of ice-cold $20 \%$ TCA. After centrifugation at $12,000 \times g$ for $10 \mathrm{~min}$ at room temperature, the supernatant is removed and discarded into a liquid radioactive waste container. The pellets were washed and centrifuged again in $10 \%$ TCA. Each sample was added $1 \mathrm{ml}$ of liquid scintillation cocktail and vortexed well, and the tubes were placed in a standard scintillation vial and counted for ${ }^{32} \mathrm{P}$. The potency of 3 -aminobenzamide (3-AB) in inhibition of PARP activity was tested by adding $20 \mu \mathrm{M} 3-\mathrm{AB}$ during the reaction before adding PARP enzyme or cell extracts. PARP activity was expressed as radioactive intensity [disintegrations per minute $(\mathrm{dpm})]$ in $20 \mu \mathrm{g}$ of cell extract protein.

Telomerase activity assay. Neurospheres were collected and washed two times with PBS and suspended in lysis buffer $(0.5 \% 3-[(3-$ cholamidopropyl)dimethylammonio]-1-propanesulfonate, $10 \mathrm{~mm}$ Tris$\mathrm{HCl}$, pH 7.5, 1 mм $\mathrm{MgCl}_{2}$, 1 mм EGTA, 5 mм 2-mercaptoethanol, 10\% glycerol, 1 U/ $\mu$ l RNaseOUT, and 1 mm PMSF). Samples (75, 150, or 750 ng of protein) were assayed for telomerase activity using the telomeric repeat amplification protocol (TRAP) (Kim et al., 1994; Weinrich et al., 1997).

\section{Results \\ TRF2 expression is upregulated during neuronal differentiation and maturation}

Immunoblot analysis of cortical homogenates showed that the expression of TRF2 was not detectable in the developing mouse cortex before E18, was present at a very low level at E18, increased markedly through postnatal day 15, and remained at high levels in the adult (Fig. 1A). To establish the cellular localization and changes in TRF2 levels during cortical development, coronal sections of mouse cerebral cortex at different development stages were immunostained with a TRF2 antibody (Fig. $1 B$ ). The majority of neurons in the developing cerebral cortex are generated from NPCs in the VZ/SVZ adjacent to the lateral ventricles. The NGNs then migrate outward through the intermediate zone (IZ) and into the cortical plate (CP), in which they form the six layers of the adult cortex. At E16 (Fig. $1 B$ ) and at earlier stages of development (data not shown), TRF2 immunoreactivity was not detected in any cells including NPCs in VZ/SVZ and NGNs in IZ and CP (Fig. 1B). At E18, TRF2 immunoreactivity appears in some neurons in the cortical plate but is absent from cells in the VZ/SVZ and IZ. At P5, all neurons in cortical plate are TRF2 positive, and the intensity of TRF2 immunoreactivity increases through P15. TRF2 immunoreactivity appeared to be localized primarily in the nucleus of neurons (Fig. $1 B$ ). These findings suggest that NPCs and NGNs express very low levels of TRF2 compared with MNs.

To elucidate the functions of telomeres and TRF2 in the processes of neural development, we used a well characterized mouse cortical NPC culture system (Ghosh and Greenberg, 1995; Cheng et al., 2003). Dissociated cell cultures are established from the cortical epithelium of E12 mice, a time when the cerebral wall consists mainly of NPCs. When dissociated cells from E12 cortical epithelium are cultured in the presence of bFGF at a relatively high density $\left(\sim 50,000\right.$ cells $\left./ \mathrm{cm}^{2}\right),>70 \%$ of the cells are proliferative NPCs that express nestin (Fig. 2A) (supplemental Fig. 1, available at www.jneurosci.org as supplemental material) (Lendahl et al., 1990; Uwanogho et al., 1995; Cheng et al., 2004). When cultured in differentiation medium lacking bFGF at a lower density $\left(20,000\right.$ cells $\left./ \mathrm{cm}^{2}\right)$, the cells cease dividing and differentiate 
A

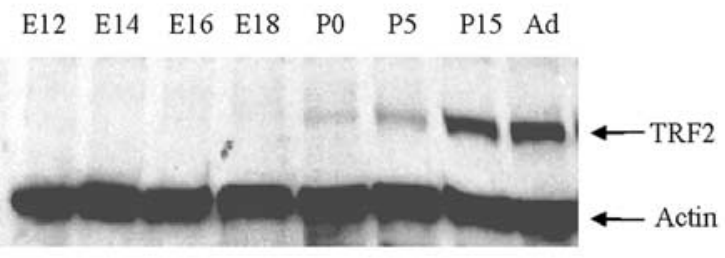

B

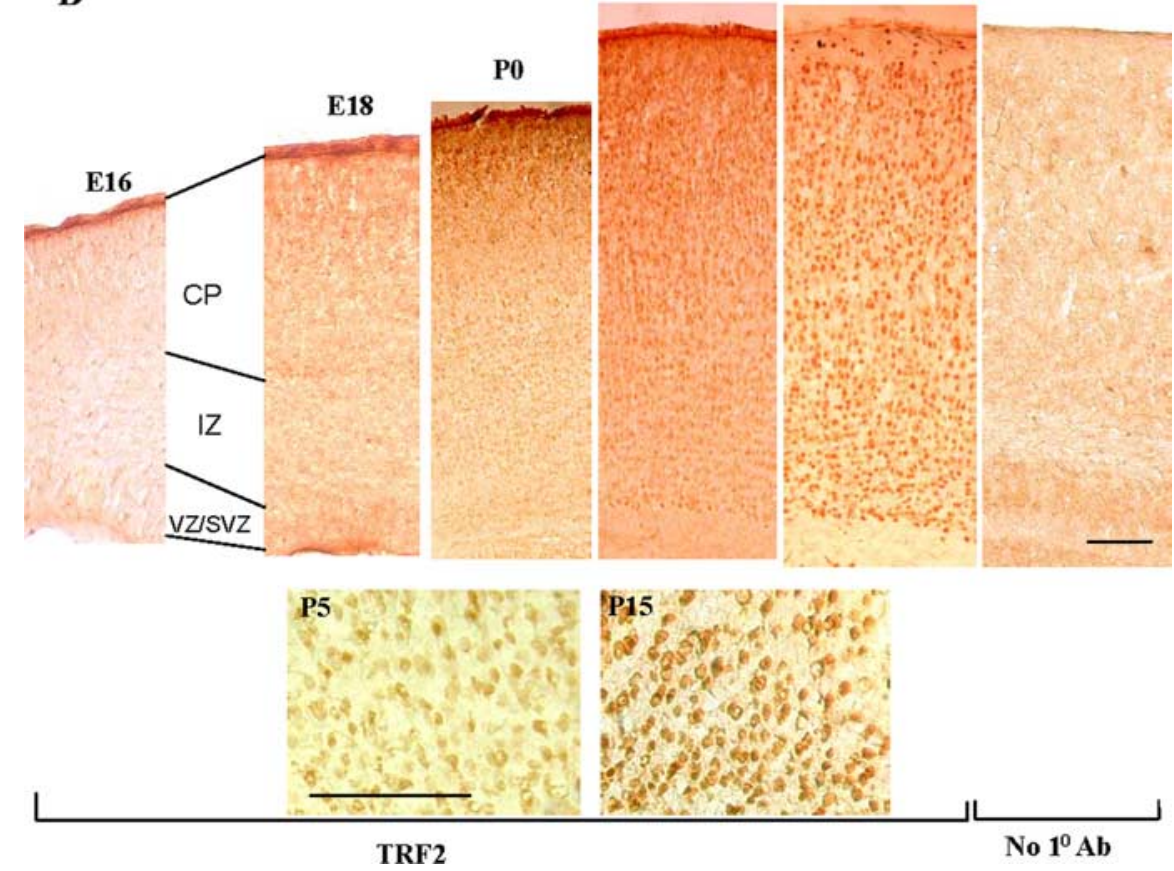

Figure 1. TRF2 expression is upregulated during development of the cerebral cortex. $\boldsymbol{A}$, The cerebral walls (early developmental stage) or cortex (late developmental stage) were removed, and tissue samples were prepared for immunoblot analysis using a TRF2 antibody; the blot was coprobed with an actin antibody. $\boldsymbol{B}$, Coronal sections of cerebral cortex immunostained with anti-TRF2 antibody. Early in development (before E18), nearly all cells are TRF2 negative, but, as development proceeds, TRF2 immunoreactivity increases. At P5, nearly all neurons are TRF2 positive (bottom left panel), and the intensity of TRF2 immunoreactivity increases through P15 (bottom right panel). AD, Adult; № $1^{\circ} \mathrm{Ab}$, section in which the primary TRF2 antibody was omitted from the protocol. Scale bar, $50 \mu \mathrm{m}$.

into neurons within $3 \mathrm{~d}$ (supplemental Fig. $1 \mathrm{~B}$, available at www.jneurosci.org as supplemental material). The NGNs arising from the NPCs differentiate in a synchronous manner, because they extend neurites and begin expressing the neuronal marker protein Tuj1 (Fig. 2A) (supplemental Fig. 1, available at www. jneurosci.org as supplemental material). By $7 \mathrm{~d}$ in culture, the neurons have matured, exhibiting elaborate dendritic and axonal arbors and expressing synaptic proteins such as synapsin (Fig. 2A) (supplemental Fig. 1, available at www.jneurosci.org as supplemental material). Consistent with cerebral cortical development in vivo (Fig. 1), little or no TRF2 was detected in cultured NPCs and NGNs, whereas TRF2 levels increased as neuronal differentiation and maturation progressed (Fig. $2 A, B$ ). Because TRF2 comes up relatively late, also correlating with glial differentiation, we did the double immunostaining of TRF2, and Tuj1 showed that TRF2 is undetectable in NGNs and abundant in MNs (Fig. 2A), indicating that upregulation of TRF2 actually comes from neuronal maturation and not from increasing glial differentiation.

\section{Newly generated neurons are highly vulnerable to telomere damage-induced apoptosis}

Previous studies have suggested antiapoptotic roles for telomerase and TRF2 in some types of mitotic cells (Fu et al., 1999; Karlseder et al., 1999). Because TRF2 levels are low in NPCs and NGNs, we tested the hypothesis that these cells may be particularly vulnerable to telomere damage. To induce selective damage to telomeres, we used telomestatin (TMS), a natural product isolated from Streptomyces anulatus 3533-SV4, which selectively interacts with the G-quadruplex DNA structures present in telomeres (Shin-ya et al., 2001; Kim et al., 2002, 2003; Chang et al., 2004). TMS increases DNA cleavage by $S 1$ nuclease at the loop regions of intramolecular G-quadruplex structures formed within telomeric sequences (Kim et al., 2003). In tumor cells, the telomere damage caused by TMS triggers apoptosis by a DNA damage response mechanism involving ATM and p53 (Tauchi et al., 2003). We evaluated the responses of NPCs, NGNs, and MNs to selective telomere damage. A $48 \mathrm{~h}$ exposure to TMS induced apoptosis of NPCs, NGNs, and MNs in a concentration-dependent manner as determined by nuclear DNA damage and chromatin condensation detected by TUNEL and Hoechst staining (Fig. 2C,D). Interestingly, NGNs were significantly more sensitive to TMS-induced apoptosis compared with NPCs and MNs (Fig. 2D). Thus, $\sim 80 \%$ of the NGNs were killed by 5 $\mu \mathrm{M}$ TMS, whereas only $20-40 \%$ of NPCs and MNs were killed.

DNA double-strand breaks (Fernandez-Capetillo et al., 2004) and telomere damage (Takai et al., 2003) elicit a DNA damage response characterized by the association of phosphorylated $\gamma$-H2AX with the lesions. Telomestatin induced a similar DNA damage response in NGNs during 3-8 h exposure periods as indicated by increased amounts of phosphorylated $\gamma-\mathrm{H} 2 \mathrm{AX}$ detected by immunoblot analysis (Fig. 3A). To further evaluate the DNA damage response and cell death pathway activated by TMS, we measured levels of PARP1, a $115 \mathrm{kDa}$ enzyme that responds to DNA damage and facilitates DNA repair (Ha and Snyder, 2000; Shall and de Murcia, 2000). Immunoblot analysis of lysates from NGNs that had been exposed to TMS for increasing time periods revealed an accumulation of high-molecular-weight PARP1immunoreactive bands within $1 \mathrm{~h}$ of exposure to TMS (Fig. $3 B$ ). These high-molecular-weight bands are likely ribosylated forms of PARP1, because activated PARP catalyzes the successive transfer of ADP-ribose units from its substrate $\mathrm{NAD}^{+}$to a variety of proteins including PARP itself to produce branched homopolymers (Ha and Snyder, 2000). As an additional test for the activation of PARP, we assayed the effect of TMS on PARP activity in the cultured cells. We found that exposure of NGNs to TMS or etoposide, a topoisomerase inhibitor that induces double-strand 
breaks in nuclear DNA (Banath and Olive, 2003; Meng et al., 2005), for $2 \mathrm{~h}$ enhanced the PARP activity to approximately twice the control level (Fig. 3C). Longer time periods of exposure of NGNs to TMS $(12-48 \mathrm{~h})$ resulted in the appearance of a PARP1-immunoreactive band of $85 \mathrm{kDa}$ (Fig. 3D), corresponding to the caspase cleavage product of PARP1 (Lazebnik et al., 1994). These findings suggest that telomere damage causes rapid activation of PARP and subsequent activation of caspases.

Apoptosis triggered by DNA damage typically involves mitochondrial alterations including release of cytochrome $c$ and/or AIF (Yu et al., 2002). Apoptosis related to telomere damage may or may not (Fu et al., 1999; Ren et al., 2001; Ramirez et al., 2003; Shammas et al., 2005) require release of cytochrome $c$ from mitochondria and subsequent caspase activation. We assessed AIF nuclear translocation and cytochrome $c$ release in TMS-treated NGNs by performing double-labeling confocal fluorescence imaging using propidium iodide to label the nuclei in combination with immunostaining with antibodies against AIF or cytochrome $c$ (Fig. $3 E)$. Telomestatin induced both cytochrome $c$ release and AIF nuclear translocation that paralleled nuclear chromatin condensation (Fig. 3E).

Cytochrome $c$ release results in the activation of caspases 9 and 3; however, PARP activation occurred much earlier than the mitochondrial dysfunction and caspase activation. To directly determine whether activation of PARP1 and/or caspases was required for apoptosis triggered by telomere damage, we used the PARP1 inhibitor 3-AB and the caspase inhibitor zVAD-fmk. 3-AB was highly effective with $20 \mu \mathrm{M}$, completely abolishing activity of purified PARP enzyme $(1 \mu \mathrm{g})$ and the activity induced by TMS and etoposide in NGNs (Fig. 3C). Telomestatin-induced death of NGNs was significantly attenuated in cultures treated with 3-AB but was not affected by zVAD-fmk at concentrations up to $100 \mu \mathrm{M}$ (Fig. $3 F$ ), indicating that telomere damage-induced cell death requires PARP1 activation but is independent of caspase activation.

\section{TRF2 protects newly generated} neurons against DNA damageinduced apoptosis

It was recently reported that TRF2 can inhibit the ATM-mediated DNA damage response in tumor cells (Karlseder et al., 2004; Celli and de Lange, 2005). ATM is rapidly recruited to sites of DNA damage in which it phosphorylates $\gamma$-H2AX
A
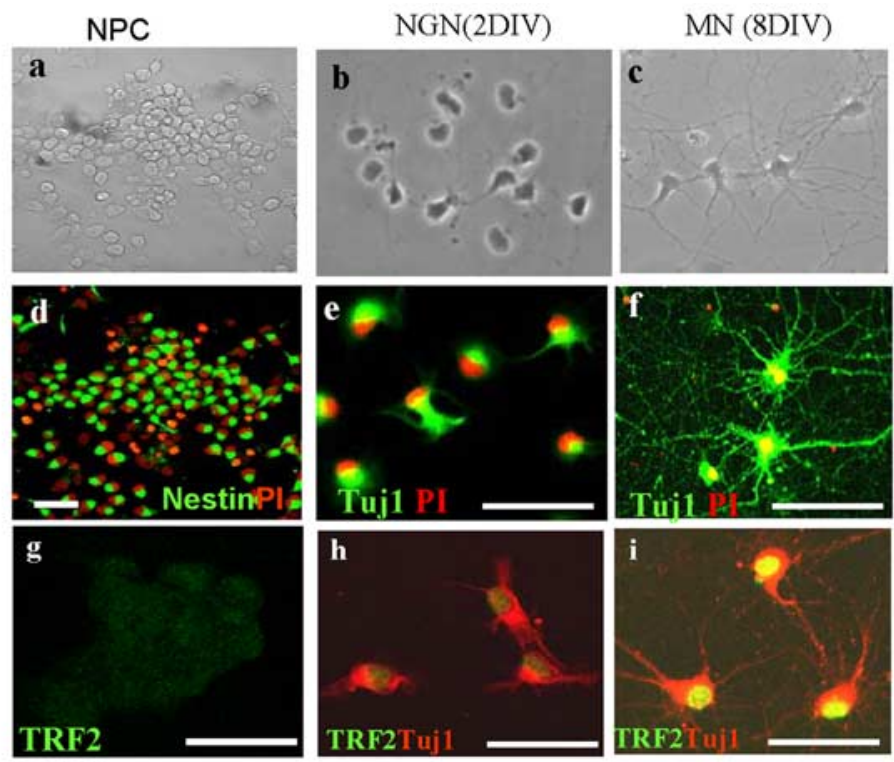

B

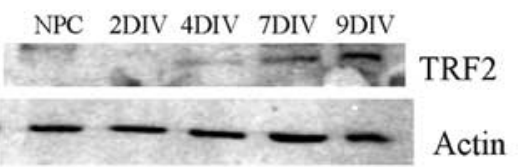

C TUNEL

Hoechst
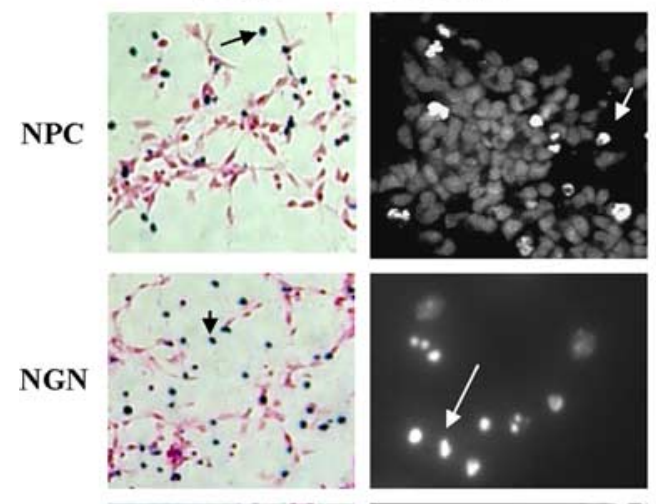

MN
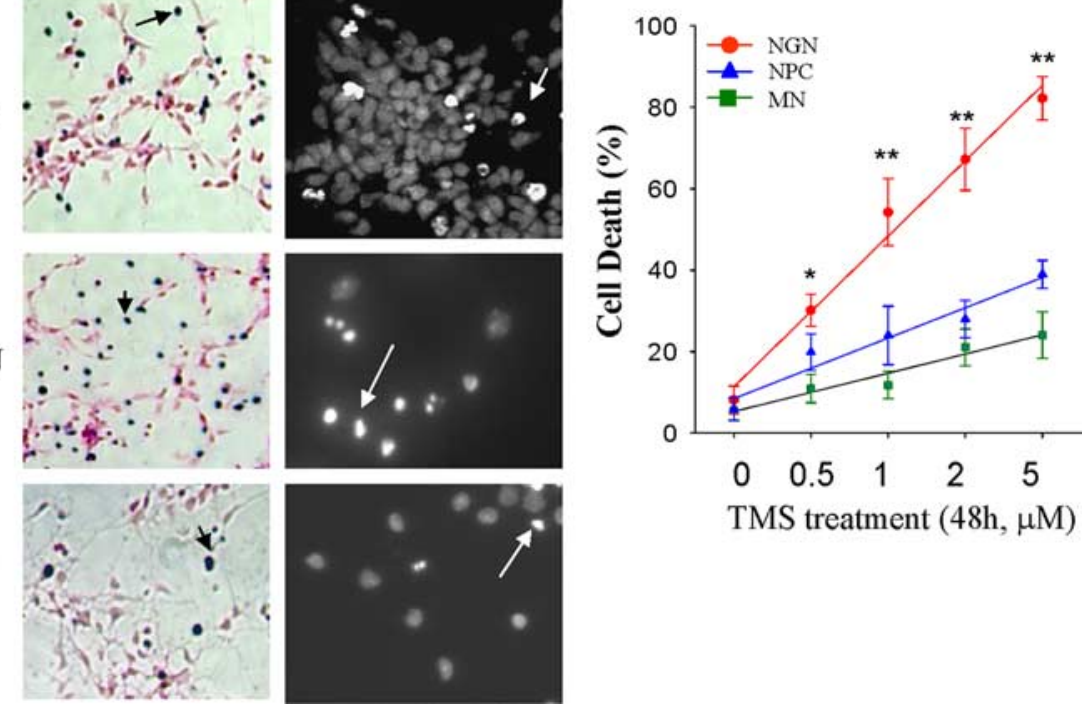

Figure 2. NGNs express low levels of TRF2 and are hypersensitive to telomere damage. $A$, Representative phase-contrast and confocal images of NPCs $(\boldsymbol{a}, \boldsymbol{d}, \boldsymbol{g})$, NGNs $(\boldsymbol{b}, \boldsymbol{e}, \boldsymbol{h})$, and MNs $(\boldsymbol{c}, \boldsymbol{f}, \boldsymbol{i})$ showing their different morphologies and the expression of molecular markers of cell identity and TRF2. Nestin ( $\boldsymbol{d}$, green), an NPC marker, $\beta 3$-tubulin (Tuj1) (e, $\boldsymbol{f}$, green; $\boldsymbol{h}, \boldsymbol{i}$, red), a neuronal marker, and TRF2 ( $\boldsymbol{g}-\boldsymbol{i}$, green). Some cells were counterstained with PI (red), a nuclear stain. $\boldsymbol{B}$, Immunoblot analysis showed that the expression of TRF2 is progressively increased as NPC differentiation and neuronal maturation proceeds. Similar results were obtained in three independent experiments. C, NPCS, NGNs, and MNs were exposed for $48 \mathrm{~h}$ to vehicle $(0 \mu \mathrm{m})$ or the indicated concentrations of TMS. Cell death was quantified using fluorescent DNA-binding dye Hoechst 33258 staining and TUNEL staining (see Materials and Methods). Images of TUNEL staining (left) and Hoechst fluorescence (right) are shown. The arrows point to examples of TUNEL-positive cells or cells with condensed nuclear DNA (Hoechst 33258 staining). D, NGNs are exquisitely sensitive to telomere damage-induced death. TUNEL-positive cells were counted, and values are expressed as a percentage of the total number of cells. Data are the means $\pm S D$ of six separate cultures in two separate experiments. Lines are linear regressions through the means. ${ }^{*} p<0.05$ and ${ }^{* *} p<0.001$ compared with the corresponding values for NPCs and MNs (ANOVA with Scheffés post hoc tests). The percentage of NGNs with condensed nuclei (quantified in Hoechst-stained cultures) after $48 \mathrm{~h}$ of exposure to TMS was also significantly greater than the percentages for NPCs and MNs ( $p<0.01$; data not shown). DIV, Days in vitro. 
A

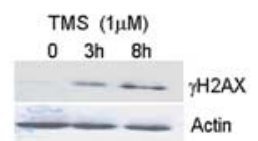

B

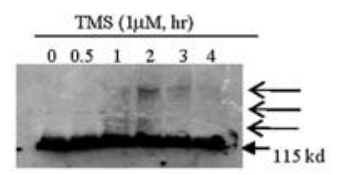

C

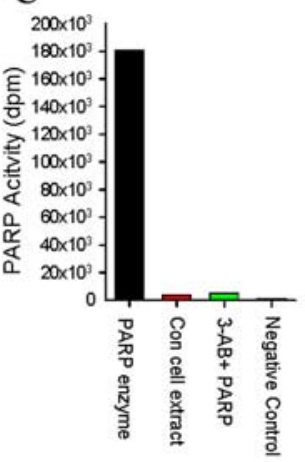

E
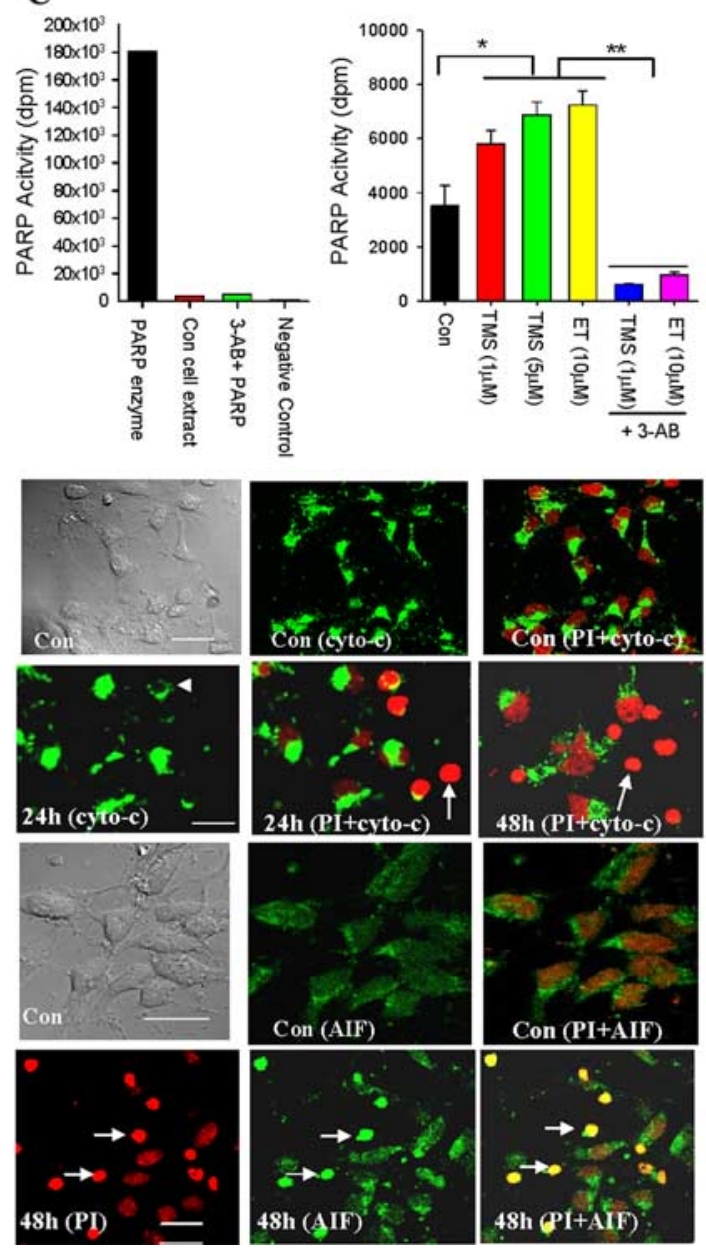

D
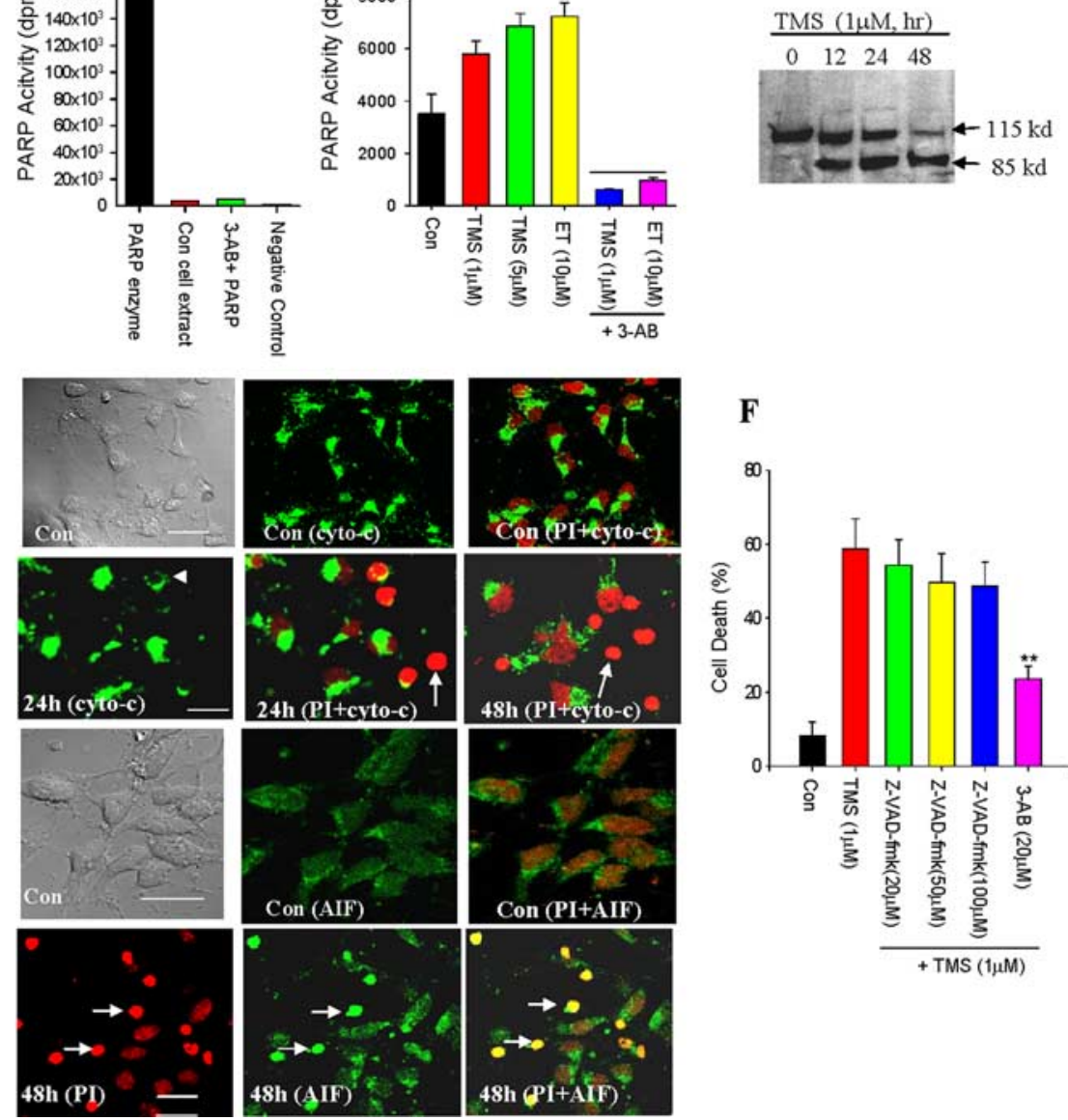

$48 h(A)$

Figure 3. Telomere disruption elicits a DNA damage response in NGNs involving phosphorylation of histone $\gamma-\mathrm{H} 2 \mathrm{AX}$ and activation and cleavage of PARP-1, resulting in caspase-independent cell death. $\boldsymbol{A}, \boldsymbol{B}$, Immunoblot analysis using antibodies against $\gamma$-H2AX phosphorylated at Ser $139(\boldsymbol{A})$ and PARP-1 $(\boldsymbol{B})$ was performed on whole-cell lysates obtained from untreated NGNs and NGNs treated for the indicated time periods with TMS. TMS treatment induced the phosphorylation of $\gamma$-H2AX. The long arrows in $\boldsymbol{B}$ point to the poly(ADP-ribosylated) forms of PARP, indicating a robust activation of PARP. The arrows in $\boldsymbol{D}$ show the uncleaved and cleaved forms of PARP. C, Cultures were exposed to TMS (1 or $5 \mu \mathrm{M}$ ) or etoposide (ET; $10 \mu \mathrm{M})$ for $2 \mathrm{~h}$ or pretreated with $20 \mu \mathrm{m}$ of the PARP inhibitor 3-AB for $30 \mathrm{~min}$ and then exposed to TMS or etoposide for $2 \mathrm{~h}$. The cell lysates were used for the assay of PARP activity. Purified PARP protein was used as a positive control (Con), and the negative control lacked PARP. The ability of 3-AB to inhibit purified PARP enzyme activity was also tested. $\boldsymbol{E}$, Telomestatin treatment induces release of cytochrome c from mitochondria and nuclear translocation of AIF in NGNs. NGNs were exposed to $1 \mu \mathrm{m}$ TMS or vehicle (control) for the indicated time periods. The cells were then immunostained using antibodies against cytochrome c (cyto-c, green) and AIF (green). All of the cells were counterstained with PI (red). Representative confocal images of NGNs immunostained with cytochrome cand AlF antibodies. Arrows point to examples of cells with condensed nuclei together with either AIF translocation into the nucleus or with cytochrome c release. $F$, A PARP inhibitor, but not a caspase inhibitor, protect NGNs against TMS-induced death. NGNs were pretreated for $1 \mathrm{~h}$ with the caspase inhibitor zVAD-fmk $(20,50$, and $100 \mu \mathrm{m})$ or the PARP inhibitor 3-AB (20 $\mu \mathrm{m})$. Cells were then exposed to $1 \mu \mathrm{m}$ TMS or vehicle as indicated, and cell death was quantified $48 \mathrm{~h}$ later by Hoechst staining. Values are the mean and SD of determinations made in at least three cultures. ${ }^{*} p<0.01 ;{ }^{* *} p<0.001$ compared with the value for cells exposed to TMS alone (ANOVA with Scheffé's post hoc tests).

(Burma et al., 2001). To determine whether TRF2 protects the telomeres of NGNs, we compared the responses to TMS of NGNs infected with either adeno-TRF2 or adeno- $\beta$ gal. Neurons infected with adeno- $\beta$ gal were used as a control for nonspecific effects of infection and overexpression of any exogenous protein.
Using a multiplicity of infection of 50 , $>90 \%$ the neurons were infected as demonstrated by $\beta$ gal staining (data not shown). TRF2 immunoreactivity was not detected in cells in cultures infected with adeno- $\beta$ gal, which is consistent with the above result that TRF2 is undetectable in NPCs and NGNs; in contrast, $>90 \%$ of the NPCs and NGNs in the cultures infected with adeno-TRF2 exhibited TRF2 immunoreactivity. In most cells, the TRF2 immunoreactivity was localized to the nucleus in which it was typically concentrated in discrete foci (Fig. 4A), consistent with a telomeric localization under physiological conditions (Karlseder et al., 2004). Telomostatin induced a large increase in levels of phosphorylated $\gamma$-H2AX within $8 \mathrm{~h}$ of exposure in cells expressing $\beta$ gal but not in cells expressing TRF2 (Fig. 4B,C), indicating that TRF2 can suppress a molecular response to telomere damage. In cultures infected with adeno- $\beta$ gal, $\sim 50 \%$ of the NGNs died within $48 \mathrm{~h}$ of exposure to TMS (Fig. 4D). In contrast, NGNs overexpressing TRF2 were highly resistant to TMS. Thus, TRF2 can protect NGNs against apoptosis induced by telomere damage, suggesting that the low level of TRF2 in NGNs may account for their hypersensitivity to telomere damage.

It was reported recently that, in cultured human fibroblasts, TRF2 rapidly associates with nontelomeric DNA in response to ultraviolet light-induced doublestrand breaks (Bradshaw et al., 2005). To determine the relative sensitivities of NPCs, NGNs, and mature neurons to generalized DNA damage, we exposed these three cell types to etoposide and camptothecin, topoisomerase inhibitors that induce doublestrand breaks in nuclear DNA (Banath and Olive, 2003; Meng et al., 2005). Etoposide and camptothecin each induced a concentration-dependent death of NPCs, NGNs, and mature neurons. NPCs and NGNs were significantly more vulnerable to each DNA-damaging agent compared with $\mathrm{MN}$ (Fig. 5A). STS is a broad-specificity protein kinase inhibitor that induces apoptosis by a mechanism that does not involve DNA damage (Roser et al., 2001). NPCs, NGNs, and MNs displayed similar vulnerabilities to STS (Fig. 5A), suggesting that NGNs are hypersensitive to death induced by telomere/ DNA damage but not that induced by other mechanisms.

Consistent with their known ability to induce double-strand breaks in DNA, both etoposide and camptothecin caused the phosphorylation of $\gamma-\mathrm{H} 2 \mathrm{AX}$ in a time-dependent manner with peak at $3 \mathrm{~h}$ (Fig. 5B). We next infected NGNs with adeno- $\beta$ gal or adeno-TRF2 and then exposed the cells to camptothecin and 
etoposide for $3 \mathrm{~h}$ or TMS for $8 \mathrm{~h}$. Levels of phosphorylated $\gamma$-H2AX were then assessed by immunoblot analysis. Levels of phosphorylated $\gamma$-H2AX were increased more in cells exposed to camptothecin or etoposide compared with those exposed to TMS (Fig. 5C,D). For each DNAdamaging agent, the amount by which levels of phosphorylated $\gamma$-H2AX was increased was significantly less in NGNs overexpressing TRF2 compared with the control NGNs. However, TRF2 was more effective in reducing phosphorylated $\gamma$-H2AX levels in cells exposed to TMS (60\% reduction) compared with those exposed to camptothecin ( $\sim 25 \%$ reduction) or etoposide ( $\sim 40 \%$ reduction) (Fig. $5 F$ ). Finally, we quantified cell death in cultures of control and TRF2-expressing NGN after exposure to etoposide, camptothecin, TMS, or staurosporine. TRF2 significantly attenuated NGN death induced by each DNA-damaging agent and was most effective in protecting the cells against TMS-induced death but had no effect on staurosporine-induced NGN apoptosis (Fig. $5 F, G$ ). Thus, TRF2 can protect NGNs against death induced by both generalized DNA damage and telomerespecific DNA damage but not apoptotic stimuli acting independently of genotoxicity.

RNA interference-mediated depletion of TRF2 increases the vulnerability of mature neurons to telomere and DNA damage

The above results indicated that developmentally upregulated TRF2 in MNs may account for their resistance to telomere/ DNA damage. To test this hypothesis, we used lentiviral-mediated expression of TRF2-specific shRNA to knockdown TRF2 expression. As a negative control, a lentiviral shRNA with a sequence that is not complementary to any known human or mouse gene was used. Four different TRF2specific shRNAs in lentiviral plasmids (pLKO.1-puro) were packaged to produce lentiviral particles, and the efficiency of each shRNA in reducing TRF2 level in MNs (48 h infection with 10 IU/cell) was determined (supplemental Fig. 2, available at www. jneurosci.org as supplemental material). Target sequence 1 was the most effective one, decreasing levels of TRF2 by $\sim 85 \%$ compared with TRF2 levels in MNs infected with the control vector (Fig. 6A) (supplemental Fig. 2A, available at www.jneurosci.org as supplemental material). TRF2 immunoreactivity was decreased by similar amounts in essentially all MNs, consistent with the well established high infection efficiency of lentivirus (Fig. $6 B)$. MNs in which TRF2 levels were decreased by RNA interference exhibited increased vulnerability to death induced by TMS and the DNA-damaging agents etoposide and camptothecin (Fig. $6 C)$. In contrast, expression of TRF2 siRNA in NGNs did not significantly increase their vulnerability to telomere or DNA damage (Fig. 6D). Consistently, MNs expressing TRF2 siRNA exhibited significantly increased levels of $\gamma$-H2AX after exposure paired Student's $t$ test.
B

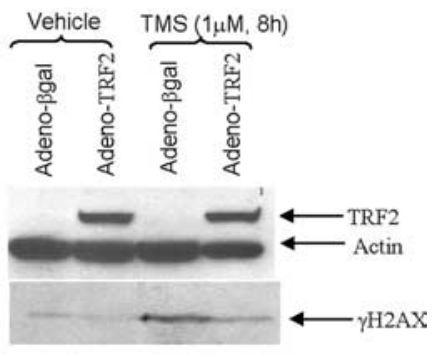

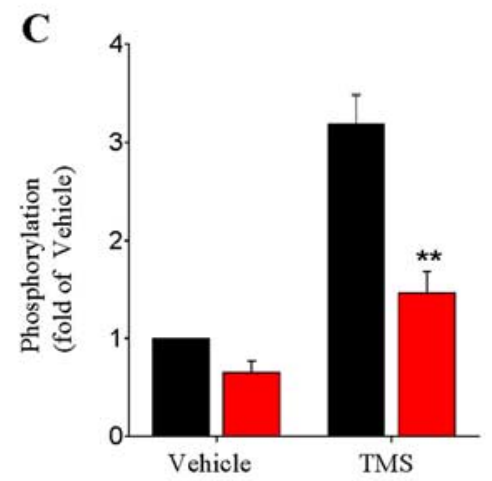

D

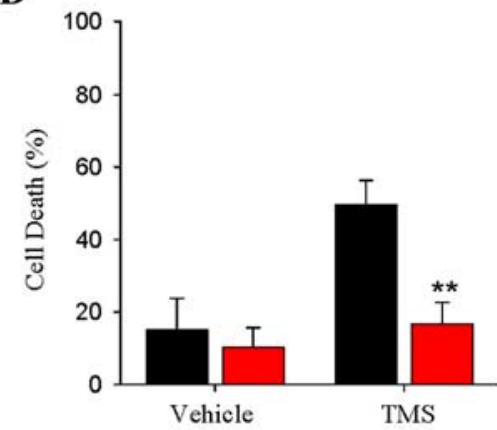

Adeno- $\beta$-gal

Adeno-TRF2

Figure 4. TRF2 suppresses the DNA damage response and protects NGNs against telomere damage-induced death. $A$, Confocal images of TRF2 immunostaining of NGNs after $2 \mathrm{~d}$ of infection with adeno- $\beta$ gal or adeno-TRF2. Endogenous TRF2 expression in is very low $(\boldsymbol{A} \boldsymbol{a})$, and the virally expressed TRF2 is mainly in the nucleus $(\boldsymbol{A} \boldsymbol{b})$ where it is concentrated in foci consistent with deno-TRE2 NGNs were treated with 1 . TMS or vahicle for 8 . Cell lysates were then subjected to immun quantified by counting cells with condensed nuclei. Data are the means $\pm S D$ of three independent experiments. ${ }^{* *} p<0.001$,

to TMS and DNA-damaging agents (Fig. 6E), suggesting that TRF2 functions to suppress DNA damage responses at telomeres and elsewhere in the genome of MNs. In contrast, expression of TRF2 siRNA in NGNs did not affect the level of $\gamma$-H2AX after exposure to TMS and DNA-damaging agents (Fig. 6 F). Control lentivirus-infected NGNs exhibited sixfold, fivefold, and threefold increases in $\gamma$-H2AX levels in response to etoposide, camptothecin, and TMS, whereas the corresponding increases in MNs were twofold, twofold, and 1.5-fold, further confirming that MNs are resistant to telomere/DNA damage encounters. Collectively, these results suggest that the low level of TRF2 in NGNs contributes significantly to their hypersensitivity to telomere and DNA damage and that TRF2 plays a neuroprotective role in MNs.

\section{NPCs lacking telomerase are highly vulnerable to telomere and DNA damage}

To understand why NPCs are relatively resistant to telomere damage compared with NGNs, despite the low level of TRF2 in the NPCs, we tested the hypothesis that telomerase protects the NPCs. Previous studies have shown that neural stem/progenitor 


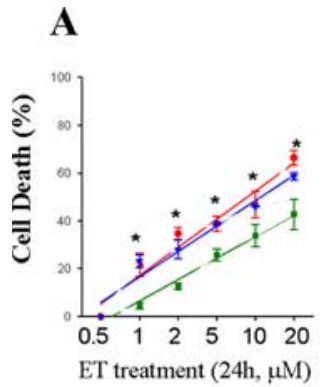

B
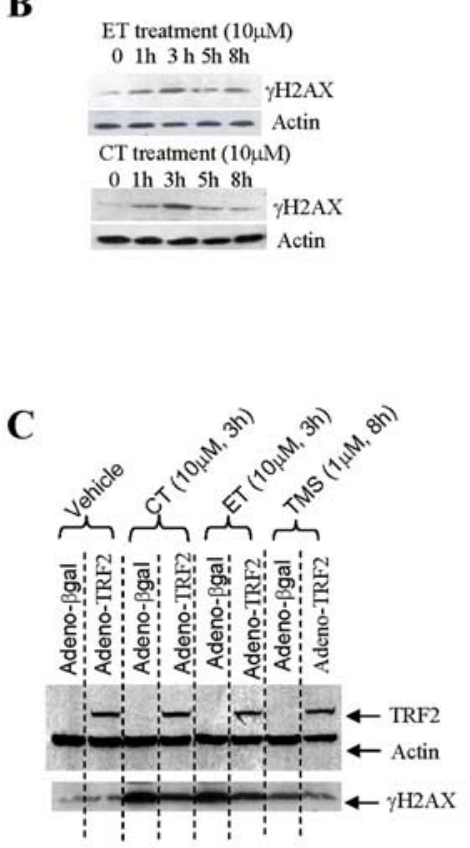
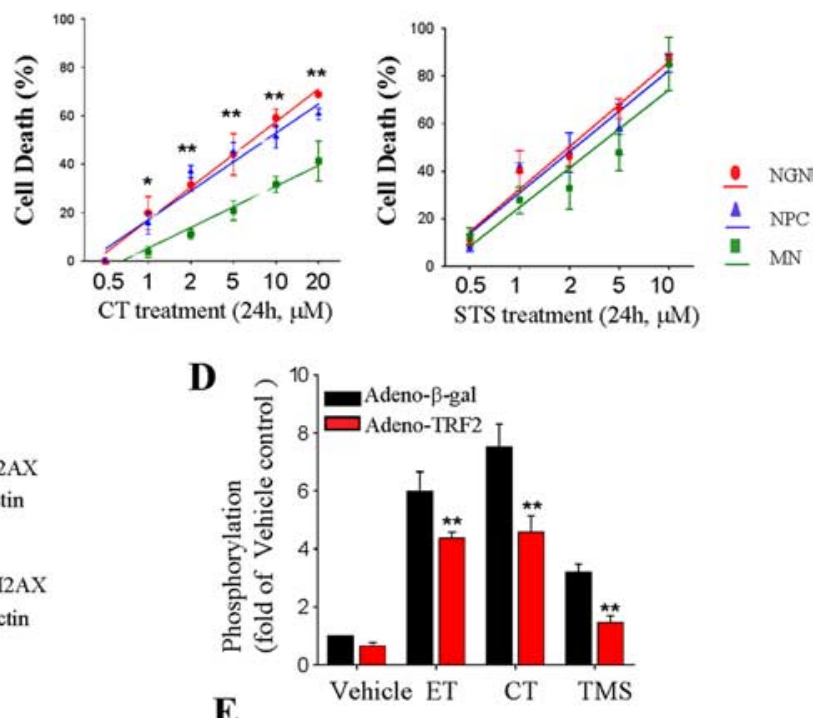

E
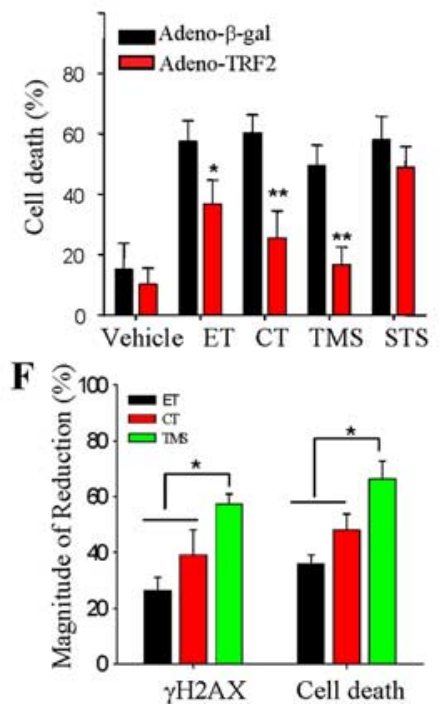

Figure 5. TRF2 protects NGNs against DNA-damaging agents. $\boldsymbol{A}$, MNs are significantly less vulnerable to death induced by topoisomerase inhibitors compared with NPCs and NGNs. In contrast, NPCs, NGNs, and MNs displayed equal vulnerability to STS-induced apoptosis. Cells were exposed to the indicated concentrations of etoposide (ET) or camptothecin (CT) or STS and then stained with Hoechst dye; cell death was quantified by counting cells with condensed nuclei. Values are the mean \pm SD of six separate cultures in two separate experiments. ${ }^{*} p<0.05$ and ${ }^{* *} p<0.001$ compared with the corresponding values for NPCs and NGNs (ANOVA with Scheffé's post hoc tests). B, NGNs were exposed to $10 \mu \mathrm{m}$ etoposide or camptothecin for $1,3,5$, or 8 h or were left untreated ( 0 time point). Proteins in cell lysates were subjected to immunoblot analysis using antibodies against phosphorylated $\mathrm{H} 2 \mathrm{AX}$ and actin. Note that both etoposide and camptothecin increased $\gamma$-H2AX levels, which reached a peak at $3 \mathrm{~h}$. $\boldsymbol{C}$, Overexpression of TRF2 significantly attenuated the $\gamma$-H2AX increase induced by etoposide or camptothecin. D, Densitometric analysis of $\gamma$-H2AX immunoblots. Values are the mean \pm SD. ${ }^{* *} p<0.001 ; n=3$. $\boldsymbol{E}$, Control (adeno- $\beta$ gal) and TRF2overexpressing NGNs were exposed to $10 \mu \mathrm{m}$ etoposide or camptothecin or $5 \mu \mathrm{m}$ STS for $24 \mathrm{~h}$ or to $1 \mu \mathrm{M}$ TMS for $48 \mathrm{~h}$, and then stained with Hoechst dye; cell death was quantified by counting cells with condensed nuclei. Values are the mean \pm SD of three independent experiments. ${ }^{* *} p<0.001$, paired Student's $t$ test. $\boldsymbol{F}$, The magnitude of reduction in levels of $\gamma$-H2AX and cell death in TRF2-overexpressing cells compared with $\beta$ gal-expressing control cells was determined for each condition (for $\gamma$-H2AX analysis, cells were exposed to $10 \mu \mathrm{m}$ etoposide or camptothecin for $3 \mathrm{~h}$ or $1 \mu \mathrm{m}$ TMS for $8 \mathrm{~h}$; for analysis of cell death, cells were exposed to $10 \mu \mathrm{m}$ etoposide or camptothecin for $24 \mathrm{~h}$ or $1 \mu \mathrm{M}$ TMS for $48 \mathrm{~h}) .{ }^{*} p<0.05$, Student's $t$ test; $n=3$ cultures. and control TERT $T^{+/+}$mice under conditions in which $>90 \%$ of the cells are NPCs (Cai et al., 2004). Telomerase activity by TRAP demonstrated that TERT $T^{+/+}$E12 neurospheres contain considerable telomerase activity, whereas TERT $T^{-1-}$ neurospheres lack telomerase activity (Fig. 7A). The vulnerability of TERT $T^{-1}$ NPCs to death induced by TMS, etoposide, and camptothecin was significantly greater than that of TERT $T^{+/+}$, indicating that telomerase protects NPCs against telomere and DNA damage (Fig. $7 B, C$ ).

\section{Discussion}

We found that TRF2 expression is low in NPCs and increases as NGNs differentiate into MNs in the developing mouse cerebral cortex and in embryonic cortical cell cultures. In contrast, the present and previous studies demonstrated that TERT expression and telomerase activity are present at high levels in NPCs, at low levels in NGNs, and are absent from mature neurons (Kruk et al., 1996; Fu et al., 2000; Klapper et al., 2001). Because TRF2 and TERT can each protect cells against telomere damage and apoptosis, our data suggest that TERT protects NPCs and TRF2 protects MNs. In contrast, NGNs are much more vulnerable to telomere damage and apoptosis because of their lack of TERT and TRF2 (Fig. 8). Our findings provide the first evidence that telomereassociated proteins can determine whether cells live or die in response to DNAdamaging insults during the process of neuronal differentiation and maturation.

TRF2 protects telomeres by facilitating t-loop formation, preventing telomere ends from signaling to the DNA damage checkpoint machinery (van Steensel et al., 1998). Previous findings suggest that telomerase can promote the survival of tumor cells (Fu et al., 1999; Zhang et al., 2003), several types of stem cells (Roy et al., 2004; Armstrong et al., 2005), and early postmitotic embryonic hippocampal neurons (Fu et al., 2000, 2002). When expressed at a sufficiently high level, telomerase appears able to play a critical protective role by preventing telomere shortening and/or by providing a protective or capping function at telomere ends (Chan and Blackburn, 2004). Although additional efforts are needed to fully understand the protective mechanisms that function at telomeres, telomerase and cells express high levels of TERT (Cai et al., 2002; Limke et al., 2003), that TERT expression is rapidly downregulated in NGNs (Kruk et al., 1996; Klapper et al., 2001), and that TERT can prevent apoptosis of several types of cells, including neural cells (Fu et al., 1999, 2000, 2002; Roy et al., 2004; Armstrong et al., 2005). We therefore cultured neurospheres from E12 TERT ${ }^{-1-}$ mice
TRF2 appear to play major roles. Rather strikingly, TRF2 is not detectable during early brain development and is upregulated during neuronal differentiation and maturation. Moreover, TRF2 upregulation and TERT downregulation during brain development lead to three distinct situations during the process of 
neuronal differentiation and maturation: NPCs with abundant TERT expression/ activity but little or low TRF2, NGNs with low levels of both TRF2 and TERT, and MNs with abundant TRF2 and little or no TERT (Fig. 8). The hypersensitivity of NGNs to telomere damage appears to be, at least in part, a consequence of their low levels of TERT and TRF2. Supporting this model, overexpression of TRF2 suppressed the telomere DNA damage response and thereby protected NGNs against apoptosis. Similarly, high level of TERT in NPCs and of TRF2 in MNs might account for their resistance to telomere/ DNA damages under physiological conditions. Consistent with this model, TRF2negative MNs and TERT ${ }^{-/-}$NPCs exhibit increased vulnerability to telomere/DNA damage. These findings indicate that neural cells express different mechanisms of telomere protection during the course of their differentiation and maturation and that the population of NGNs is lacking in two major protective mechanisms, resulting in a high degree of sensitivity to telomere damage compared with NPCs and MNs. Many NGNs in the developing and adult brain undergo a form of programmed cell death called apoptosis (Rich, 1992; Lewin and Barde, 1996; Agerman et al., 2000). Our data suggest that unprotected telomeres in NGNs may be one factor contributing to the apoptosis of NGNs in the developing and adult brain.

Previous studies showed that TMS has a G-quadruplex-interacting structure that allows it to selectively intercalate in telomeres, thereby disturbing telomere structure and preventing telomere elongation in mitotic cells (Kim et al., 2002; Tauchi et al., 2003). Telomestatin increases DNA cleavage by $\mathrm{S} 1$ nuclease at the loop regions of intramolecular G-quadruplex structures formed within telomeric sequences (Kim et al., 2003); this results in a DNA damage response involving ATM and p53 (Tauchi et al., 2003). We found that TMS induced phosphorylation of histone $\gamma$-H2AX and activation of PARP-1 in NGNs, both of which are early DNA damage responses. TRF2 also associates with genomic double-strand breaks as an early response to DNA damage and inhibits phosphorylation of ATM signaling targets (Bradshaw et al., 2005). In the present study, TRF2 attenuated the phosphorylation of $\gamma$-H2AX and protected NGNs from death induced by etoposide and camptothecin, topoisomerase inhibitors that induce double-strand breaks in nuclear DNA (Banath and Olive, 2003; Meng et al., 2005). However, TRF2 was more effective in protecting NGNs against TMS-induced death, consistent with its localization and function at telomeres. Telomere damage can trigger apoptosis by activating a DNA damage response pathway

$\mathbf{F}$
$\mathbf{B}$

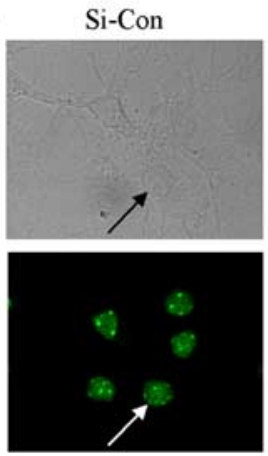

Si-TRF2
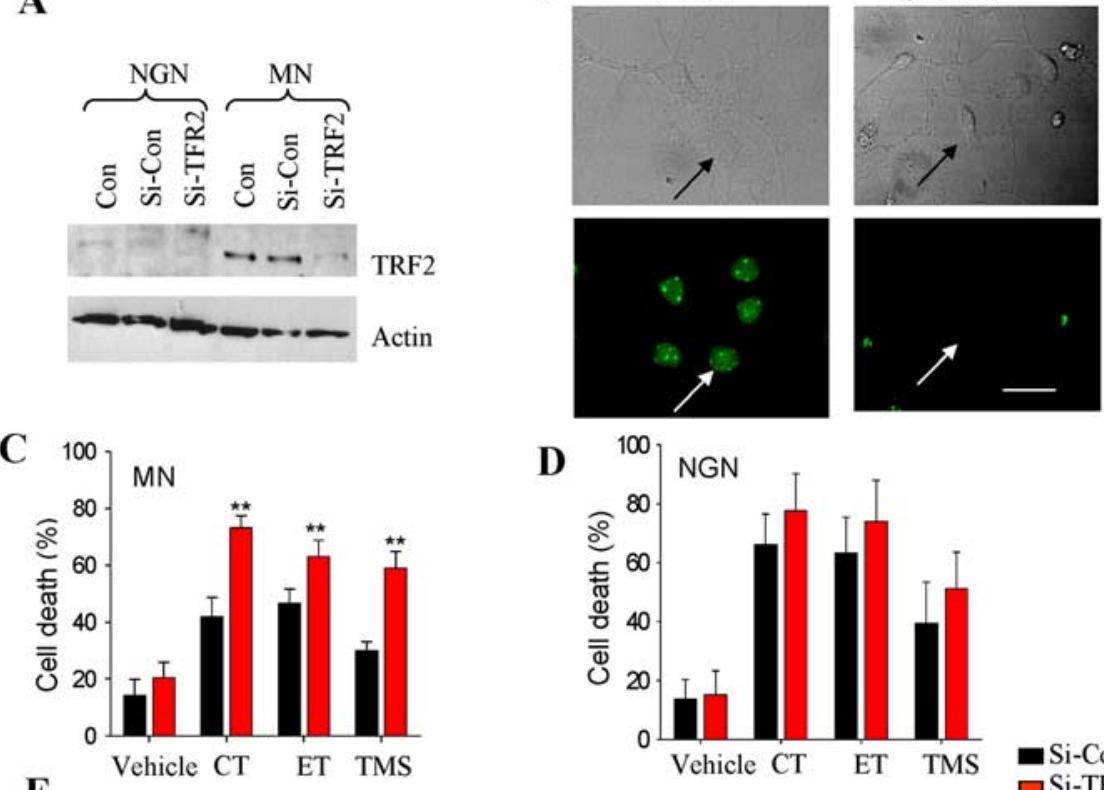

- $\mathrm{Si}$-Con
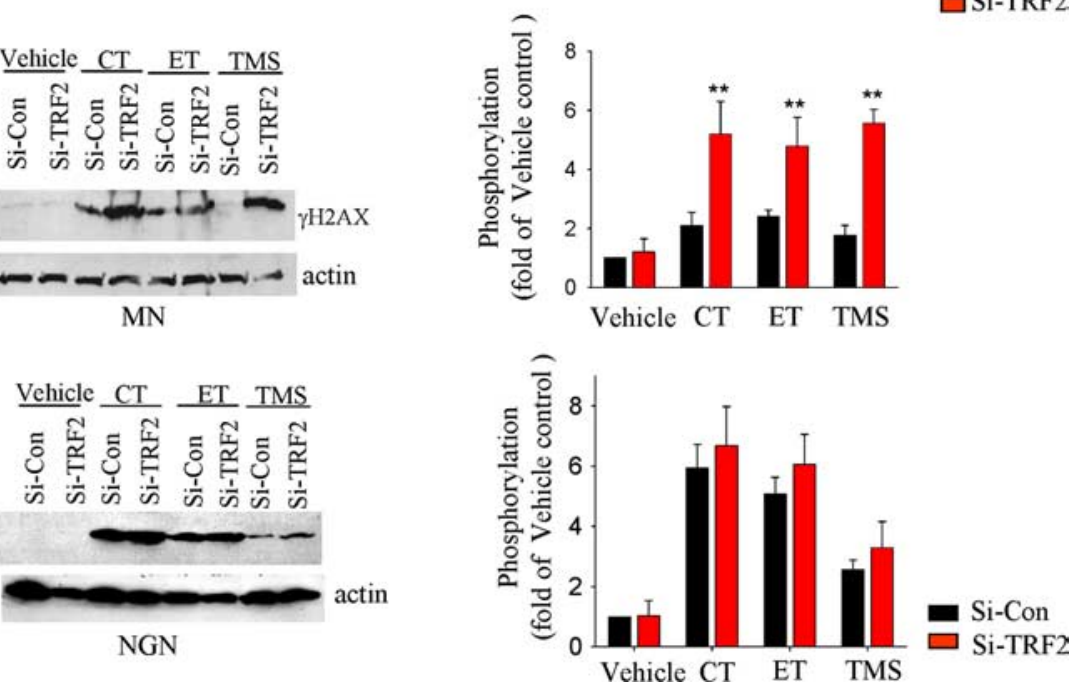

Figure 6. RNA interference-mediated depletion of TRF2 renders mature neurons vulnerable to telomere and DNA damage. NGNs and MNs were infected with a lentiviral vector containing shRNA directed against TRF2 mRNA (Si-TRF2) or a control lentiviral vector with a nonsense shRNA sequence (Si-Con); additional cells were not exposed to virus (Con). $A$, At $48 \mathrm{~h}$ after infection, cell lysates were subjected to immunoblots using antibodies against TRF 2 and $\beta$-actin. $B$, At $48 \mathrm{~h}$ after infection, cells were immunostained with TRF2 antibodies. Arrows show the same cells in transmitted light and immunofluorescence images. C, D, MNs expressing TRF2 siRNA exhibit increased vulnerability to cell death induced by telomere and DNA-damaging agents, whereas the vulnerability of NGNs is unaffected by TRF2 siRNA expression. $\boldsymbol{E}, \boldsymbol{F}$, MNs expressing TRF2 siRNA exhibit increased $\gamma$-H2AX levels after exposure to TMS, etoposide (ET), or camptothecin (CT), whereas $\gamma$-H2AX levels in NGNs are unaffected by TRF2 siRNA expression. At $48 \mathrm{~h}$ after infection, NGNs and MNs were exposed to camptothecin (10 $\mu \mathrm{M})$, etoposide (10 $\mu \mathrm{M})$, or TMS $(1 \mu \mathrm{M})$ for either $24 \mathrm{~h}$ (cell death analysis) or $3 \mathrm{~h}$ ( $\gamma$-H2AX analysis). Cell death was quantified by Hoechst dye staining, and phosphorylation of histone $\mathrm{H} 2 \mathrm{AX}$ was analyzed by densitometric analysis of $\gamma-\mathrm{H} 2 \mathrm{AX}$ immunoblots. Values are the mean $\pm \mathrm{SD}$ of three independent experiments. ${ }^{* *} p<0.001$, paired Student's $t$ test.

involving ATM and p53, with subsequent mitochondrial changes resulting in the release of cytochrome $c$ and caspase activation ( Fu et al., 1999; Karlseder et al., 1999; Shammas et al., 2005). We found that TMS induces a similar DNA damage-related apoptotic cascade in NGNs. Caspase-3 activation occurred in response to TMS as indicated by a delayed proteolytic cleavage of PARP to produce an $86 \mathrm{kDa}$ fragment, the PARP caspase- 3 cleavage product. However, in contrast to the caspase-dependent cell death induced by DNA-damaging agents such as camptothecin and 

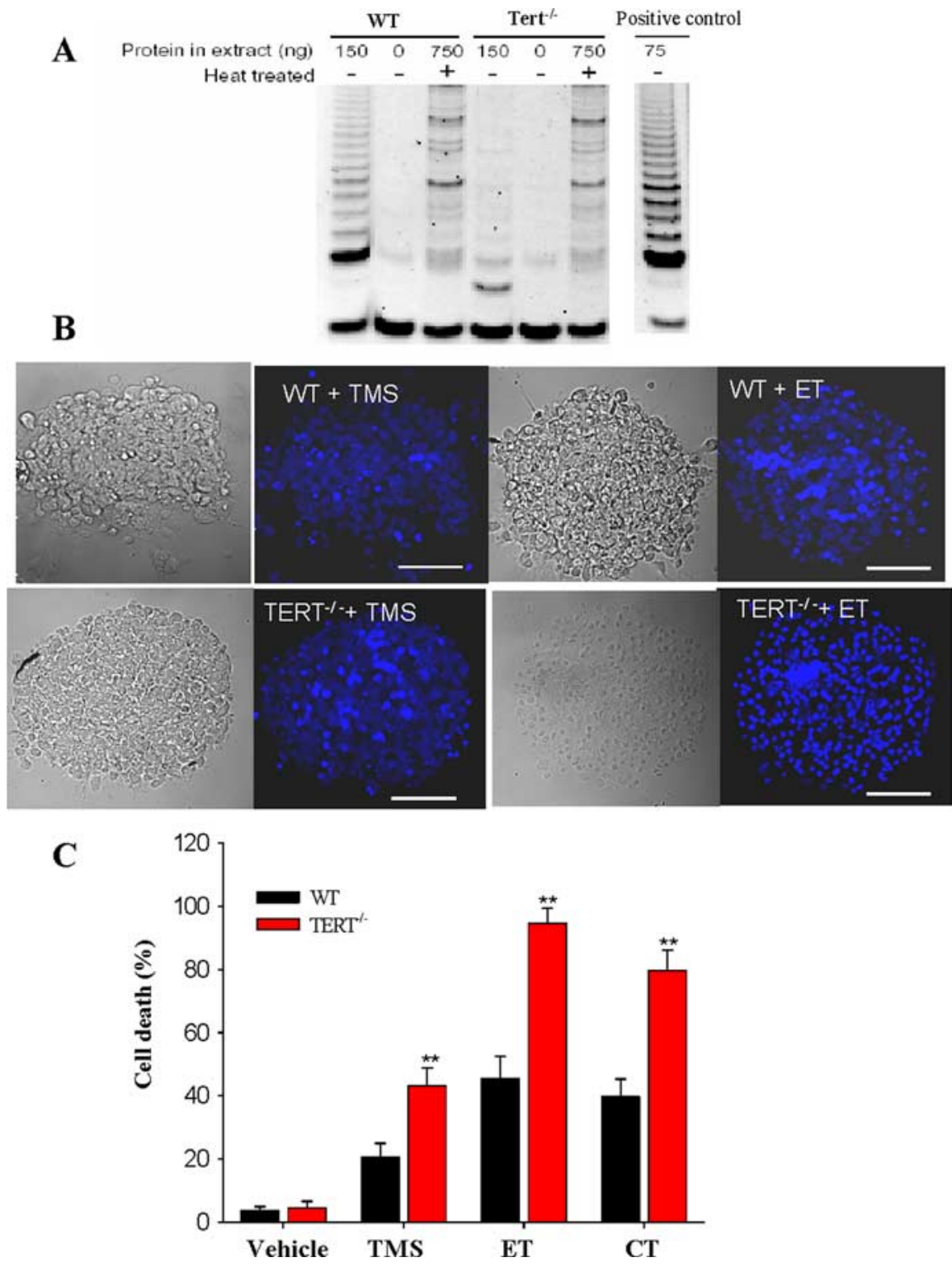

Figure 7. Telomerase protects NPCs against telomere and DNA damage. A, NPCs from TERT ${ }^{-1-}$ mice lack telomerase activity. TRAP assay analysis of telomerase activity in lysates $(150 \mathrm{ng}$ ) of cortical neurosphere cultures from E12 wild-type (WT) and TERT knock-out $\left(\right.$ TERT $\left.^{-\prime-}\right)$ mice. As negative controls, the cell lysates $(750 \mathrm{ng})$ were incubated for $10 \mathrm{~min}$ at $85^{\circ} \mathrm{C}$. HeLa cell lysate $(75$ ng) was used as a positive control. $B, C$, TERT $^{-/-}$NPCs are significantly more vulnerable to telomere and DNA damage. Four hours after plating on poly-L-lysine-coated coverslips, wild-type and TERT ${ }^{-1-}$ neurospheres were treated with TMS (2 $\left.\mu \mathrm{M}\right)$, etoposide $(\mathrm{ET} ; 10 \mu \mathrm{m})$, or camptothecin $(\mathrm{CT} ; 10 \mu \mathrm{m})$ for $24 \mathrm{~h}$. Cell death was quantified by counting cells with condensed nuclei in acquired images by confocal laser scanning microscopy after Hoechst staining. Values are the mean \pm SD of three independent experiments. ${ }^{* *} p<0.001$, paired Student's $t$ test.

etoposide (Morris and Geller, 1996; Park et al., 1998; Xiang et al., 1998; Stefanis et al., 1999; Keramaris et al., 2000; Morris et al., 2001; Rideout et al., 2001), TMS-induced cell death was caspaseindependent because it was not prevented by the caspase inhibitor zVAD-fmk. Caspase-independent apoptosis has also been observed in neuronal cells in response to $\beta$-amyloid, nitric oxide, and traumatic brain injury (Okuno et al., 1998; Selznick et al., 2000; Zhang et al., 2002) and in the models of photoreceptor cell death both in vivo (Carmody and Cotter, 2000) and in vitro (Donovan and Cotter, 2002). Previous studies showed that TMS increases DNA cleavage by $\mathrm{S} 1$ nuclease at both loop regions in an asymmetric way in G-quadruplex structures (Kim et al., 2003), and we found that TMS induces a rapid activation of PARP- 1 and $\gamma \mathrm{H} 2 \mathrm{AX}$, consistent with a DNA damage response. PARP-1 protects the genome by functioning in the DNA damage surveillance network. PARP-1 is a mediator of cell death in ischemia-reperfusion injury (Eliasson et al., 1997; Endres et al., 1997), glutamate excitotoxicity (Zhang et al., 1995; Mandir et al., 2000), and various inflammatory processes (Szabo and Dawson, 1998). The molecular mechanism of PARP-1-induced cell death is not clear. Yu et al. (2002) reported that PARP-1 activation is required for AIF nuclear translocation and that AIF is necessary for PARP-1-dependent cell death. Telomere damage-induced death of NGNs appears to involve a similar sequence of PARP-1 activation and translocation of AIF from the mitochondria to the nucleus.

Telomeres are dynamic structures in mitotic cells in which several different interconvertible structural conformations have been described, including capped t-loop and extended telomeres and uncapped telomeres (Neidle and Parkinson, 2003). The upregulation of TRF2 during brain development might indicate that there is a transition of telomere structures from a more dynamic state at the NPC stage to a more stable and secured TRFdependent t-loop structure in postmitotic neurons. The resulting telomere stabilization and suppression of telomerase activity may be critical for maintenance of the differentiated state and the prevention of apoptosis. The upregulation of TRF2 expression in association with neuronal differentiation and maturation during cortical development suggests a role for TRF2 in regulating neuroprotection and neuronal differentiation. Consistent with this possibility, TRF2 is upregulated in embryonal carcinoma cells during neural differentiation induced by retinoic acid, and overexpression of TRF2 in COS cells induces them to form neurite-like processes (Jung et al., 2004). The functions of telomeres and telomere-associated proteins in neural development and adult plasticity are likely to be complex. It is increasingly appreciated that telomeres are not simply structures that prevent erosion of chromosome ends in proliferative cells. Indeed, several proteins that associate with telomeres are known to be involved in the activation of signal transduction pathways designed to control cell proliferation, differentiation, and/or cell survival, including DNA-dependent protein kinase, Ku70/80, and PARP1 (Smogorzewska and de Lange, 2004). Our data suggest that TRF2 is one such telomere-associated protein that is involved in regulating the fate of developing embryonic cerebral cortical cells. Future studies will further elucidate the molecular signaling mechanisms upstream and downstream of changes in telomeres and their roles in neural cell differentiation and survival. 


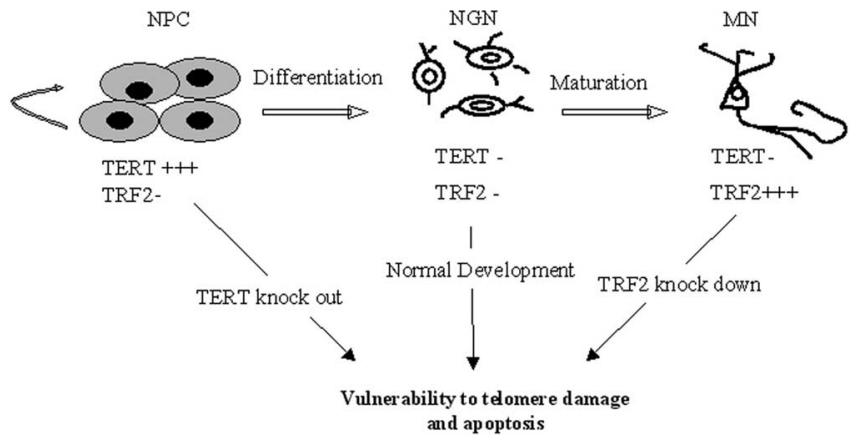

Figure 8. Model for the roles of TRF2 and TERT in the regulation of neuronal survival and differentiation. NPCs express high levels of TERT but low levels of TRF2. TERT promotes NPC survival. NGNs, which normally have low levels of both TERT and TRF2, are highly sensitive to telomere and DNA damage and apoptosis. MNs, which have low levels of TERT and high levels of TRF2, are relatively resistant to telomere and DNA damage and apoptosis. Depletion of TRF2 from MNs by RNA interference technology (knockdown) renders the MNs vulnerable to telomere and DNA damage and apoptosis. Thus, TRF2, TERT, and telomere state play important roles in determining the vulnerability of NPCs, NGNs, and MNs during brain development.

\section{References}

Agerman K, Baudet C, Fundin B, Willson C, Ernfors P (2000) Attenuation of a caspase-3 dependent cell death in NT4- and p75-deficient embryonic sensory neurons. Mol Cell Neurosci 16:58-68.

Armstrong L, Saretzki G, Peters H, Wappler I, Evans J, Hole N, von Zglinicki T, Lako M (2005) Overexpression of telomerase confers growth advantage, stress resistance, and enhanced differentiation of ESCs toward the hematopoietic lineage. Stem Cells 23:516-529.

Banath JP, Olive PL (2003) Expression of phosphorylated histone H2AX as a surrogate of cell killing by drugs that create DNA double-strand breaks. Cancer Res 63:4347-4350.

Bilaud T, Brun C, Ancelin K, Koering CE, Laroche T, Gilson E (1997) Telomeric localization of TRF2, a novel human telobox protein. Nat Genet $17: 236-239$.

Blackburn EH (2001) Switching and signaling at the telomere. Cell 106:661-673

Bradshaw PS, Stavropoulos DJ, Meyn MS (2005) Human telomeric protein TRF2 associates with genomic double-strand breaks as an early response to DNA damage. Nat Genet 37:193-197.

Broccoli D, Smogorzewska A, Chong L, de Lange T (1997) Human telomeres contain two distinct Myb-related proteins, TRF1 and TRF2. Nat Genet 17:231-235.

Burma S, Chen BP, Murphy M, Kurimasa A, Chen DJ (2001) ATM phosphorylateshistone H2AX in response to DNA double-strand breaks. J Biol Chem 276:42462-42467.

Cai J, Wu Y, Mirua T, Pierce JL, Lucero MT, Albertine KH, Spangrude GJ, Rao MS (2002) Properties of a fetal multipotent neural stem cell (NEP cell). Dev Biol 251:221-240.

Cai J, Cheng A, Luo Y, Lu C, Mattson MP, Rao MS, Furukawa F (2004) Membrane properties of rat embryonic multipotent neural stem cells. J Neurochem 88:212-226.

Caporaso GL, Lim DA, Alvarez-Buylla A, Chao MV (2003) Telomerase activity in the subventricular zone of adult mice. Mol Cell Neurosci 23:693-702.

Carmody RJ, Cotter TG (2000) Oxidative stress induces caspaseindependent retinal apoptosis in vitro. Cell Death Differ 7:282-291.

Celli GB, de Lange T (2005) DNA processing is not required for ATMmediated telomere damage response after TRF2 deletion. Nat Cell Biol 7:712-718.

Chan SR, Blackburn EH (2004) Telomeres and telomerase. Philos Trans R Soc Lond B Biol Sci 359:109-121.

Chang CC, Kuo IC, Ling IF, Chen CT, Chen HC, Lou PJ, Lin JJ, Chang TC (2004) Detection of quadruplex DNA structures in human telomeres by a fluorescent carbazole derivative. Anal Chem 76:4490-4494.

Cheng A, Wang S, Rao MS, Mattson MP (2003) Nitric oxide acts in a positive feedback loop with BDNF to regulate neural progenitor cell proliferation and differentiation in the mammalian brain. Dev Biol 258:319-333.

Cheng A, Tang H, Cai J, Zhu M, Zhang X, Rao M, Mattson MP (2004) Gap junctional communication is required to maintain mouse cortical neural progenitor cells in a proliferative state. Dev Biol 272:203-216.

Chiang YJ, Hemann MT, Hathcock KS, Tessarollo L, Feigenbaum L, Hahn WC, Hodes RJ (2004) Expression of telomerase RNA template, but not telomerase reverse transcriptase, is limiting for telomere length maintenance in vivo. Mol Cell Biol 24:7024-7031.

Donovan M, Cotter TG (2002) Caspase-independent photoreceptor apoptosis in vivo and differential expression of apoptotic protease activating factor-1 and caspase-3 during retinal development. Cell Death Differ 9:1220-1231

Eliasson MJ, Sampei K, Mandir AS, Hurn PD, Traystman RJ, Bao J, Pieper A, Wang ZQ, Dawson TM, Snyder SH, Dawson VL (1997) Poly(ADPribose) polymerase gene disruption renders mice resistant to cerebral ischemia. Nat Med 3:1089-1095.

Endres M, Wang ZQ, Namura S, Waeber C, Moskowitz MA (1997) Ischemic brain injury is mediated by the activation of poly(ADPribose)polymerase. J Cereb Blood Flow Metab 17:1143-1151.

Fernandez-Capetillo O, Lee A, Nussenzweig M, Nussenzweig A (2004) H2AX: the histone guardian of the genome. DNA Repair 3:959-967.

Frank KM, Sharpless NE, Gao Y, Sekiguchi JM, Ferguson DO, Zhu C, Manis JP, Horner J, DePinho RA, Alt FW (2000) DNA ligase IV deficiency in mice leads to defective neurogenesis and embryonic lethality via the p53 pathway. Mol Cell 5:993-1002.

Fu W, Begley JG, Killen MW, Mattson MP (1999) Anti-apoptotic role of telomerase in pheochromocytoma cells. J Biol Chem 274:7264-7271.

Fu W, Killen M, Culmsee C, Dhar S, Pandita TK, Mattson MP (2000) The catalytic subunit of telomerase is expressed in developing brain neurons and serves a cell survival-promoting function. J Mol Neurosci 14:3-15.

Fu W, Lu C, Mattson MP (2002) Telomerase mediates the cell survivalpromoting actions of brain-derived neurotrophic factor and secreted amyloid precursor protein in developing hippocampal neurons. J Neurosci 22:10710-10719.

Ghosh A, Greenberg ME (1995) Distinct roles for bFGF and NT-3 in the regulation of cortical neurogenesis. Neuron 15:89-103.

Griffith JD, Comeau L, Rosenfield S, Stansel RM, Bianchi A, Moss H, de Lange $\mathrm{T}$ (1999) Mammalian telomeres end in a large duplex loop. Cell 97:503-514.

Gross CG (2000) Neurogenesis in the adult brain: death of a dogma. Nat Rev Neurosci 1:67-73.

Ha HC, Snyder SH (2000) Poly(ADP-ribose) polymerase-1 in the nervous system. Neurobiol Dis 7:225-239.

Herrup K, Neve R, Ackerman SL, Copani A (2004) Divide and die: cell cycle events as triggers of nerve cell death. J Neurosci 24:9232-9239.

Jung Y, Lee S, Bang S, Kim S, Choi K, Lee C, Lee SG, Kim CJ, Song K, Lee I (2004) TRF2 is in neuroglial cytoplasm and induces neurite-like processes. FEBS Lett 557:129-132.

Karlseder J, Broccoli D, Dai Y, Hardy S, de Lange T (1999) p53- and ATMdependent apoptosis induced by telomeres lacking TRF2. Science 283:1321-1325.

Karlseder J, Smogorzewska A, de Lange T (2002) Senescence induced by altered telomere state, not telomere loss. Science 295:2446-2449.

Karlseder J, Hoke K, Mirzoeva OK, Bakkenist C, Kastan MB, Petrini JH, de Lange T (2004) The telomeric protein TRF2 binds the ATM kinase and can inhibit the ATM-dependent DNA damage response. PLoS Biol 2:E240.

Keramaris E, Stefanis L, MacLaurin J, Harada N, Takaku K, Ishikawa T, Taketo MM, Robertson GS, Nicholson DW, Slack RS, Park DS (2000) Involvement of caspase 3 in apoptotic death of cortical neurons evoked by DNA damage. Mol Cell Neurosci 15:368-379.

Kim MY, Vankayalapati H, Shin-Ya K, Wierzba K, Hurley LH (2002) Telomestatin, a potent telomerase inhibitor that interacts quite specifically with the human telomeric intramolecular g-quadruplex. J Am Chem Soc 124:2098-2099.

Kim MY, Gleason-Guzman M, Izbicka E, Nishioka D, Hurley LH (2003) The different biological effects of telomestatin and TMPyP4 can be attributed to their selectivity for interaction with intramolecular or intermolecular G-quadruplex structures. Cancer Res 63:3247-3256.

Kim NW, Piatyszek MA, Prowse KR, Harley CB, West MD, Ho PL, Coviello GM, Wright WE, Weinrich SL, Shay JW (1994) Specific association of human telomerase activity with immortal cells and cancer. Science 266:2011-2015.

Klapper W, Shin T, Mattson MP (2001) Differential regulation of telomer- 
ase activity and TERT expression during brain development in mice. J Neurosci Res 64:252-260.

Kruk PA, Balajee AS, Rao KS, Bohr VA (1996) Telomere reduction and telomerase inactivation during neuronal cell differentiation. Biochem Biophys Res Commun 224:487-492.

Kruman II, Wersto RP, Cardozo-Pelaez F, Smilenov L, Chan SL, Chrest FJ, Emokpae Jr R, Gorospe M, Mattson MP (2004) Cell cycle activation linked to neuronal cell death initiated by DNA damage. Neuron 41:549-561.

Kuan CY, Roth KA, Flavell RA, Rakic P (2000) Mechanisms of programmed cell death in the developing brain. Trends Neurosci 23:291-297.

Lazebnik YA, Kaufmann SH, Desnoyers S, Poirier GG, Earnshaw WC (1994) Cleavage of poly(ADP-ribose) polymerase by a proteinase with properties like ICE. Nature 371:346-347.

Lee J, Duan W, Mattson MP (2002) Evidence that brain-derived neurotrophic factor is required for basal neurogenesis and mediates, in part, the enhancement of neurogenesis by dietary restriction in the hippocampus of adult mice. J Neurochem 82:1367-1375.

Lee Y, Barnes DE, Lindahl T, McKinnon PJ (2000) Defective neurogenesis resulting from DNA ligase IV deficiency requires Atm. Genes Dev 14:2576-2580.

Lendahl U, Zimmerman LB, McKay RD (1990) CNS stem cells express a new class of intermediate filament protein. Cell 60:585-595.

Lewin GR, Barde YA (1996) Physiology of the neurotrophins. Annu Rev Neurosci 19:289-317.

Lie DC, Song H, Colamarino SA, Ming GL, Gage FH (2004) Neurogenesis in the adult brain: new strategies for central nervous system diseases. Annu Rev Pharmacol Toxicol 44:399-421.

Limke TL, Cai J, Miura T, Rao MS, Mattson MP (2003) Distinguishing features of progenitor cells in the late embryonic and adult hippocampus. Dev Neurosci 25:257-272.

Mandir AS, Poitras MF, Berliner AR, Herring WJ, Guastella DB, Feldman A, Poirier GG, Wang ZQ, Dawson TM, Dawson VL (2000) NMDA but not non-NMDA excitotoxicity is mediated by Poly(ADP-ribose) polymerase. J Neurosci 20:8005-8011.

McConnell SK (1995) Constructing the cerebral cortex: neurogenesis and fate determination. Neuron 15:761-768.

McEachern MJ, Krauskopf A, Blackburn EH (2000) Telomeres and their control. Annu Rev Genet 34:331-358.

Meng LH, Kohlhagen G, Liao ZY, Antony S, Sausville E, Pommier Y (2005) DNA-protein cross-links and replication-dependent histone H2AX phosphorylation induced by aminoflavone (NSC 686288), a novel anticancer agent active against human breast cancer cells. Cancer Res 65:5337-5343.

Miller FD, Pozniak CD, Walsh GS (2000) Neuronal life and death: an essential role for the p53 family. Cell Death Differ 7:880-888.

Morris EJ, Geller HM (1996) Induction of neuronal apoptosis by camptothecin, an inhibitor of DNA topoisomerase-I: evidence for cell cycleindependent toxicity. J Cell Biol 134:757-770.

Morris EJ, Keramaris E, Rideout HJ, Slack RS, Dyson NJ, Stefanis L, Park DS (2001) Cyclin-dependent kinases and P53 pathways are activated independently and mediate Bax activation in neurons after DNA damage. J Neurosci 21:5017-5026.

Neidle S, Parkinson G (2003) The structure of telomeric DNA. Curr Opin Struct Biol 13:275-283.

Okuno S, Shimizu S, Ito T, Nomura M, Hamada E, Tsujimoto Y, Matsuda H (1998) Bcl-2 prevents caspase-independent cell death. J Biol Chem 273:34272-34277.

Park DS, Morris EJ, Padmanabhan J, Shelanski ML, Geller HM, Greene LA (1998) Cyclin dependent kinases participate in death of neurons evoked by DNA-damaging agents. J Cell Biol 143:457-467.

Price J, Williams B, Grove E (1992) The generation of cellular diversity in the cerebral cortex. Brain Pathol 2:23-29.

Ramirez R, Carracedo J, Jimenez R, Canela A, Herrera E, Alijama P, Blasco MA (2003) Massive telomere loss is an early event of DNA damageinduced apoptosis. J Biol Chem 278:836-842.

Ren JG, Xia HL, Just T, Dai YR (2001) Hydroxyl radical-induced apoptosis in human tumor cells is associated with telomere shortening but not telomerase inhibition and caspase activation. FEBS Lett 488:123-132.
Rich KM (1992) Neuronal death after trophic factor deprivation. J Neurotrauma 9 [Suppl 1]:61-69.

Rideout HJ, Zang E, Yeasmin M, Gordon R, Jabado O, Park DS, Stefanis L (2001) Inhibitors of trypsin-like serine proteases prevent DNA damageinduced neuronal death by acting upstream of the mitochondrial checkpoint and of p53 induction. Neuroscience 107:339-352.

Roser S, Pool-Zobel BL, Rechkemmer G (2001) Contribution of apoptosis to responses in the comet assay. Mutat Res 497:169-175.

Roy NS, Nakano T, Keyoung HM, Windrem M, Rashbaum WK, Alonso ML, Kang J, Peng W, Carpenter MK, Lin J, Nedergaard M, Goldman SA (2004) Telomerase immortalization of neuronally restricted progenitor cells derived from the human fetal spinal cord. Nat Biotechnol 22:297-305.

Selznick LA, Zheng TS, Flavell RA, Rakic P, Roth KA (2000) Amyloid betainduced neuronal death is bax-dependent but caspase-independent J Neuropathol Exp Neurol 59:271-279.

Shall S, de Murcia G (2000) Poly(ADP-ribose) polymerase-1: what have we learned from the deficient mouse model? Mutat Res 460:1-15.

Shammas MA, Koley H, Batchu RB, Bertheau RC, Protopopov A, Munshi NC, Goyal RK (2005) Telomerase inhibition by siRNA causes senescence and apoptosis in Barrett's adenocarcinoma cells: mechanism and therapeutic potential. Mol Cancer 4:24.

Shin-ya K, Wierzba K, Matsuo K, Ohtani T, Yamada Y, Furihata K, Hayakawa Y, Seto H (2001) Telomestatin, a novel telomerase inhibitor from Streptomyces anulatus. J Am Chem Soc 23:1262-1263.

Smogorzewska A, de Lange T (2004) Regulation of telomerase by telomeric proteins. Annu Rev Biochem 73:177-208.

Stefanis L, Park DS, Friedman WJ, Greene LA (1999) Caspase-dependent and -independent death of camptothecin-treated embryonic cortical neurons. J Neurosci 19:6235-6247.

Szabo C, Dawson VL (1998) Role of poly(ADP-ribose) synthetase in inflammation and ischaemia-reperfusion. Trends Pharmacol Sci 19:287-298.

Takai H, Smogorzewska A, deLange T (2003) DNA damage foci at dysfunctional telomeres. Curr Biol 13:1549-1556.

Tauchi T, Shin-Ya K, Sashida G, Sumi M, Nakajima A, Shimamoto T, Ohyashiki JH, Ohyashiki K (2003) Activity of a novel G-quadruplexinteractive telomerase inhibitor, telomestatin(SOT-095), against human leukemia cells: involvement of ATM-dependent DNA damage response pathways. Oncogene 22:5338-5347.

Uwanogho D, Rex M, Cartwright EJ, Pearl G, Healy C, Scotting PJ, Sharpe PT (1995) Embryonic expression of the chicken Sox2, Sox 3 and Sox 11 genes suggests an interactive role in neuronal development. Mech Dev 49:23-36.

van Steensel B, Smogorzewska A, de Lange T (1998) TRF2 protects human telomeres from end-to-end fusions. Cell 92:401-413.

Weinrich SL, Pruzan R, Ma L, Ouellette M, Tesmer VM, Holt SE, Bodnar AG, Lichtsteiner S, Kim NW, Trager JB, Taylor RD, Carlos R, Andrews WH, Wright WE, Shay JW, Harley CB, Morin GB (1997) Reconstitution of human telomerase with the template RNA component hTR and the catalytic protein subunit hTRT. Nat Genet 17:498-502.

Xiang H, Kinoshita Y, Knudson CM, Korsmeyer SJ, Schwartzkroin PA, Morrison RS (1998) Bax involvement in p53-mediated neuronal cell death. J Neurosci 18:1363-1373.

Yu SW, Wang H, Poitras MF, Coombs C, Bowers WJ, Federoff HJ, Poirie GG, Dawson TM, Dawson VL (2002) Mediation of poly(ADP-ribose) polymerase-1-dependent cell death by apoptosis-inducing factor. Science 297:259-263

Zhang J, Pieper A, Snyder SH (1995) Poly(ADP-ribose) synthetase activation: an early indicator of neurotoxic DNA damage. J Neurochem 65:1411-1414.

Zhang P, Chan SL, Fu W, Mendoza M, Mattson MP (2003) TERT suppresses apoptosis at a premitochondrial step by a mechanism requiring reverse transcriptase activity and 14-3-3 protein-binding ability. FASEB J 17:767-769.

Zhang X, Chen J, Graham SH, Du L, Kochanek PM, Draviam R, Guo F, Nathaniel PD, Szabo C, Watkins SC, Clark RS (2002) Intranuclear localization of apoptosis-inducing factor (AIF) and large scale DNA fragmentation after traumatic brain injury in rats and in neuronal cultures exposed to peroxynitrite. J Neurochem 82:181-191. 